\title{
Eurydesma-Lyonia fauna (Early Permian) from the Itararé group, Paraná Basin (Brazil): A paleobiogeographic W-E trans-Gondwanan marine connection
}

\author{
Arturo César Taboada ${ }^{\text {a,e }}$, Jacqueline Peixoto Neves ${ }^{\text {b,* }}$, Luiz Carlos Weinschütz ${ }^{\text {c }}$, \\ Maria Alejandra Pagani ${ }^{\mathrm{d}, e}$, Marcello Guimarães Simões ${ }^{\mathrm{b}}$ \\ a Centro de Investigaciones Esquel de Montaña y Estepa Patagónicas (CIEMEP), CONICET-UNPSJB, Roca 780, Esquel (U9200), Chubut, Argentina

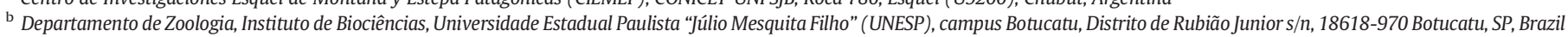 \\ ${ }^{c}$ Universidade do Contestado, CENPALEO, Mafra, SC, Brazil \\ ${ }^{d}$ Museo Paleontológico Egidio Feruglio(MEF), Avenida Fontana n 140, Trelew (U9100GYO), Chubut, Argentina \\ e CONICET, Consejo Nacional de Investigaciones Científicas y Técnicas, Argentina
}

\section{A R T I C L E I N F O}

\section{Article history:}

Received 14 September 2015

Received in revised form 22 January 2016

Accepted 9 February 2016

Available online 23 February 2016

\section{Keywords:}

Itararé group

Early Permian

Eurydesma

Lyonia

Biocorrelation

W-E Gondwana marine connection

\begin{abstract}
A B S T R A C T
Here, the biocorrelation of the marine invertebrate assemblages of the post-glacial succession in the uppermost portion of the Late Paleozoic Itararé Group (Paraná Basin, Brazil) is for the first time firmly constrained with other well-dated Gondwanan faunas. The correlation and ages of these marine assemblages are among the main controversial issues related to Brazilian Gondwana geology. In total, 118 brachiopod specimens were analyzed, and at least seven species were identified: Lyonia rochacamposi sp. nov., Langella imbituvensis (Oliveira),? Streptorhynchus sp.,? Cyrtella sp., Tomiopsis sp. cf. T. harringtoni Archbold and Thomas, Quinquenella rionegrensis (Oliveira) and Biconvexiella roxoi Oliveira. The presence of Tomiopsis sp. cf. T. harringtoni and the bivalve Atomodesma (Aphanaia) orbirugata (Harrington) in the Teixeira Soares beds plus Myonia argentinensis (Harrington) and Heteropecten paranaensis Neves et al., both of which recorded in deposits in the Teixeira Soares and Mafra beds (Butiá), suggests a biocorrelation with the Eurydesma fauna from the Bonete Formation, Sauce Grande-Colorado Basin, Argentina. Furthermore, the presence of Lyonia Archbold and Praeundulomya cf. subelongata Dickins in the Taciba Formation indicates affinities with deposits in the Lyons Group, Carnarvon Basin, and the Fossil Cliff Member, Perth Basin (Western Australia), suggesting a late Asselian-early Sakmarian age. Even more importantly, the collected data suggest the existence of an W-E trans-Gondwanan marine seaway between the Paraná (Brazil), Sauce Grande-Colorado (Argentina), Huab (Hardap shale of the Dwyka Group, Aranos area, Namibia, southwest Africa), the Carnavon (Western Australia) basins, and beyond eastward to the Cimmerian region. A V proto-rift system through two major axes of extensional basin development facilitated the W-E marine connection. Main axes formed by a north-northwesterly trending axis paralleling the future South Atlantic and a broadly north-northeasterly trending line of separation related to the future Indian Ocean. This proto-rift system coupled with a sea-level rise of at least $100 \mathrm{~m}$, favored the establishment of a long narrow shallow seaway, allowing the exchange of Eurydesma fauna between eastern and western Gondwana.
\end{abstract}

(c) 2016 Elsevier B.V. All rights reserved.

\section{Introduction}

The Gondwanan affinity of the Permian marine macrofossils of the Itararé Group (Bashkirian/Moscovian-early Permian, Holz et al. 2010), Paraná Basin, is well known on the basis of its molluskan faunas, particularly those recorded in some strata from southern Brazil (Rocha Campos and Rösler, 1978; Neves et al., 2014a, b). The marine

\footnotetext{
* Corresponding author.

E-mail addresses: ataboada@unpata.edu, artaboadaart@gmail.com (A.C. Taboada), nevesjp.unesp@gmail.com (J.P. Neves), luizw@unc.br (L.C. Weinschütz), apagani@mef.org.ar (M.A. Pagani), profsimoes@gmail.com (M.G. Simões).
}

assemblages recorded in the upper portion of the Taciba Formation cropping out in the Mafra and Teixeira Soares regions, in the states of Santa Catarina and Paraná, respectively, are especially noteworthy. The Taciba Formation records a succession of depositional environments tied to the demise of late Paleozoic glaciation (França and Potter, 1988; Santos et al., 1996; Mineropar, 2007). The faunal assemblages are poorly diversified, showing a scattered distribution, both vertically and geographically, and are mainly dominated by bivalve mollusks (Rocha Campos, 1967; Simões et al., 1998, 2012; Neves et al., 2014a, b). These occurrences have been known since E.P. Oliveira announced the discovery of marine macrofossils in that unit in 1908 in a letter to Woodworth (1912, in Lange, 1954). These fossils were 
subsequently studied by various authors (Oliveira, 1930; Mendes, 1952, Lange, 1952; Kegel and Costa, 1952; Beurlen, 1954; Rocha Campos, 1966, 1969, among others). However, more comprehensive contributions regarding the taxonomic composition, age and affinities of these marine fossils have only been reported recently (Simões et al., 2012; Neves et al., 2014a, b). On the basis of the presence of Myonia argentinensis (Harrington, 1955), Atomodesma (Aphanaia) orbirugata (Harrington, 1955) and Heteropecten paranaensis (Neves et al., 2014a), researchers have emphasized the correlation of the Taciba bivalve fauna with those of the Eurydesma-bearing Bonete Formation, Pillahuincó Group, Sauce Grande-Colorado Basin, Buenos Aires Province, Argentina. This indicates a possible Asselian age for the postglacial bivalve fauna of the Taciba Formation. However, our view regarding the marine fossils of the Taciba Formation is mainly "bivalvecentric" (= biased towards this mollusk class). Indeed, much less is known about the identity, affinities and age of the brachiopods of the Taciba Formation, which co-occur in the same lithofacies. In this paper, we describe, illustrate and discuss, in modern terms, a surprisingly "diverse" and well-preserved brachiopod fauna of the Taciba Formation. Although these faunas have been known since Oliveira (1930) and Rocha Campos $(1966,1969)$, we have added new information on the composition and age of the marine invertebrate faunas recorded in the uppermost portion of the Itararé Group. Furthermore, reexamination of faunal affinities allowed us to improve our understanding of the paleobiogeographical relationships between close and/or coeval Gondwanan faunas of southern Brazil (Paraná Basin) with other South American and Patagonian late Paleozoic basins (Sauce GrandeColorado, Uspallata-Iglesia and Tepuel-Genoa basins) as well as those of South Africa (western Kalahari/Aranos Basin) and Western Australia (Carnarvon, Canning, Perth basins). In this context, a new paleobiogeographic hypothesis is presented and discussed.

\section{General geological setting}

Carboniferous to early Permian glacial-related successions in the intracratonic Paraná Basin (Brazil) are recorded at the base of the Gondwana 1 Supersequence (Milani et al., 2007). These glacial non-marine and glaciomarine rocks are referred to as the Itararé Group, $\mathrm{a} \sim 1500 \mathrm{~m}$ thick unit that includes conglomerates, diamictites, sandstones, rhythmites, mudstones, shales, and a few coal seams (Milani et al., 2007; Holz et al., 2008, 2010). These rocks rest unconformably either on metamorphic/igneous Precambrian-pre-Silurian basement or sedimentary Devonian strata (Rocha Campos, 1967; Holz et al., 2008).

In the study area, in the states of Santa Catarina and Paraná (Fig. 1), the Itararé Group comprises rocks belonging to the Taciba Formation. According to França and Potter (1988), this unit encompasses a third major fining upward cycle of the Itarare Group including three members (i.e., in ascending order the Rio Segredo sandstone, Chapéu do Sol diamictite, and Rio do Sul rhythmite, siltstone, and shale; see also Castro, 1999; Weinschutz and Castro, 2004, 2005, 2006). The Taciba Formation is equivalent to the Rio do Sul Formation, in the sense of Schneider et al. (1974) (excluding the basal Lontras shale).

In the Mafra region, in the state of Santa Catarina (Fig. 1C), Weinschutz and Castro (2006) have recognized two main depositional sequences within the Taciba succession, which were generated under glacial and post-glacial conditions (Taciba I and II), respectively (Fig. 2). In outcrops, the deglacial interval (Taciba II) comprises a succession of a 10 m-thick stratified diamictite, overlain by thin stratified conglomerate and sandstone and an intensely bioturbated, fossil-rich sandstone, which is succeeded by shales (Weinschutz and Castro, 2006; Simões et al., 2012) (Fig. 2). As noted below, most of the studied brachiopods come from that sandstone bed (= Butiá assemblage, sense Rocha Campos and Rösler, 1978) (Table 1).

In the Imbituva and Teixeira Soares regions, in the state of Paraná (Figs. 1A, B, respectively), only the upper portion of the Taciba Formation crops out (Lange, 1952; Mineropar, 2007; Neves et al., 2014b), which includes diamictites, sandstones, siltstones and mudstones (Passinho shale), succeeded by the sand-dominated, coal-bearing deposits of the lower portion of the Sakmarian-Artinskian, Rio Bonito Formation (Fig. 3) (see below in Stratigraphy and Locality).

\section{Material and methods}

\subsection{Fossil collection}

In total, 118 brachiopod specimens from the Taciba Formation were examined: 1 specimen from fossil site A, 11 from fossil site B and 106 from fossil site $C$ (see Tables 2 and 3). These specimens are housed in distinct Brazilian invertebrate fossil collections, including aCENPALEO (Centro de Paleontologia), Universidade de Contestado, Mafra, Santa Catarina State; b- Departamento de Zoologia, Instituto de Biociências, Universidade Estadual Paulista "Júlio de Mesquita Filho" (UNESP), Botucatu, São Paulo State; and c- Instituto de Geociências, Universidade de São Paulo, São Paulo State. Other material (Crurithyris sp.) is housed at the Laboratorio de Investigaciones em Evolución y Biodiversidad (LIEB), Universidad de la Patagonia "San Juan Bosco", Esquel, Chubut, Argentina.

Abbreviations.- CP, Cenpaleo collection; DZP, Department of Zoology, Paleontology collection, UNESP, Botucatu campus; DGM, Division of Geology and Mineralogy, National Department of Mineral Production, Rio de Janeiro State. Materials with the DGM prefix are housed in the University of São Paulo collection, while GP-1E indicates Institute of Geosciences collection, University of São Paulo, USP, São Paulo, Brazil, and LIEB-PI indicates the LIEB invertebrate fossil collection.

In the laboratory, the fossil material was prepared according to standard paleontological procedures (see Feldmann et al., 1989) using precision tools. Latex casts and plasticine molds were prepared for most of the shells. Brachiopod and bivalve shells were also coated with magnesium oxide sublimate to enhance diagnostic morphological characters for photography (see Neves et al., 2014a, b and references therein). The applied classification largely follows Waterhouse (2013) for Linproductidina, Williams and Brunton (2000) for Orthotetidina, Carter et al. (2006) for Spiriferidina, Carter and Johnson (2006) for Spiriferinidina, Racheboeuf (2000) for Chonetidina and Williams et al. (2000) for Lingulida.

\subsection{Stratigraphy and locality}

Brachiopods come from three main fossil sites in the states of Paraná (Teixeira Soares) and Santa Catarina (Mafra) in southern Brazil. Table 1 summarizes the main geographic and geologic information for the sampled localities (fossil sites A, B and C). In the study area, the geology and the correlation of the strata of the Itarare Group are relatively well known (see Almeida, 1945; Rocha Campos, 1966; Weinschutz and Castro, 2006; Mineropar, 2007; Neves et al., 2014b). Here the Taciba Formation (França and Potter, 1988) comprises the uppermost unit of the Itarare Group (Fig. 4). In Teixeira Soares County, in the state of Paraná, the rocks of this formation are exposed along the Almas River Valley, $4 \mathrm{~km} \mathrm{SE}$ of the town of Teixeira Soares (Oliveira, 1930; Lange, 1954; Almeida, 1945; Mineropar, 2007; Neves et al., 2014b). Locally, the Taciba Formation is a $\sim 45 \mathrm{~m}$ thick, siliciclastic succession including, in ascending order, a thick $(\sim 10 \mathrm{~m})$, polymitic, matrix-supported, massive diamictite with rounded, striated and faceted clasts (granules/boulders) of granites, which may grade upward to crudely stratified mudstones (Mineropar, 2007, p. 106). These are succeeded by $\mathrm{a} \sim 7 \mathrm{~m}$-thick package of medium-to-fine grained sandstones (Rio da Areia sandstone) with planar cross-stratifications (see Mineropar, 2007, p. 107). In these sandstones, Planolites-like traces are associated with ripple marks, and bivalve-dominated shell pavements occur in the uppermost $(2 \mathrm{~m})$ portion, above which thin $(50 \mathrm{~cm})$, deeply bioturbated fossil-bearing siltstones (Baitaca siltstone) including scattered, splayed-out bivalve shells are recorded (Neves et al., 2014b, p. 212). 


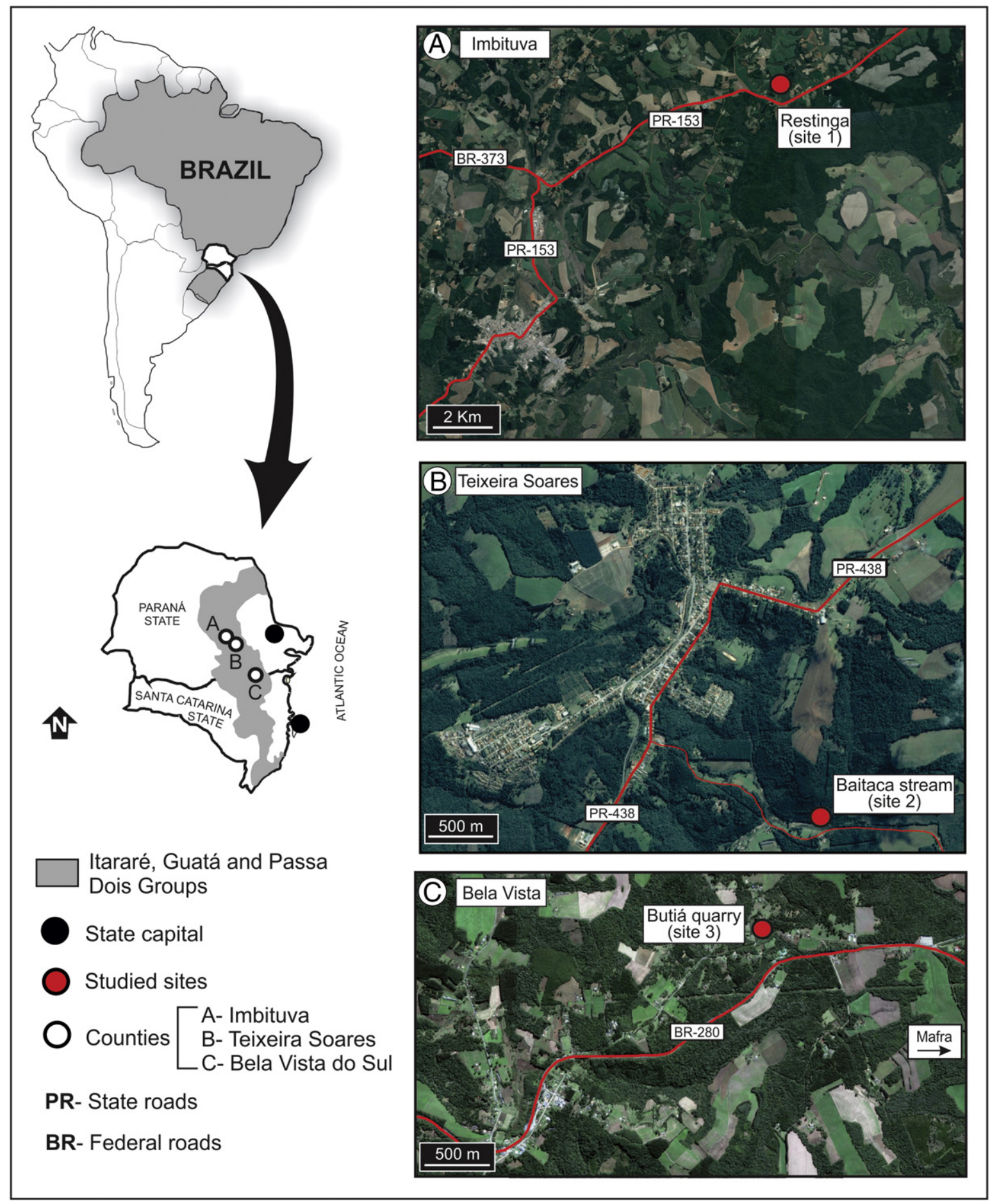

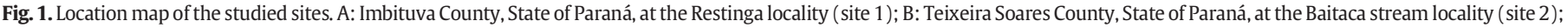
C: Mafra County, State of Santa Catarina, at the Bela Vista do Sul locality, Butiá quarry, (site 3).

Toward the top, a thick $(2.15 \mathrm{~m})$ succession including fine-to-very fine, well-sorted sandstones with low-angle trough cross-stratifications occurs. This sandstone is intensely bioturbated, including in situ bivalve shells, escape structures, and rare rhynchonelliform brachiopods. Above this, thick ( $>30 \mathrm{~m}$ ), laterally persistent (tabular), dark grey (or white-yellowish when weathered), thinly laminated mudstones (Passinho shale) are recorded (Almeida, 1945; Mineropar, 2007; Neves et al., 2014b, p. 206), which may contain rare splayed-out bivalve shells or isolated valves of linguliform brachiopods (Oliveira, 1930).

The succession described above reflects a stratigraphy composed of alternating units, including (a) proximal re-deposited diamictites generated in proximal settings, succeeded by (b) strata deposited in nearshore (upper shoreface) and (c) inner (lower shoreface)- to (d) outer-shelf (offshore) environments (Mineropar, 2007; Neves et al., 2014b) tied to the demise of the LPIA (Late Paleozoic Ice Age). Regionally, the Passinho shale marks the maximum flooding surface of the Itararé succession (Santos et al., 1996; Mineropar, 2007; Holz et al., 2010; Neves et al., 2014b) (Fig. 2). These mudstones are capped by the fluvio-deltaic, coal-bearing deposits of the Sakmarian-Artinskian Rio Bonito Formation (Santos et al., 1996; Holz et al., 2010). At the Restinga locality, near Imbituva County, in the state of Paraná (Fig. 1A), the Passinho shale also crops out at Km 42 of the PR-153 


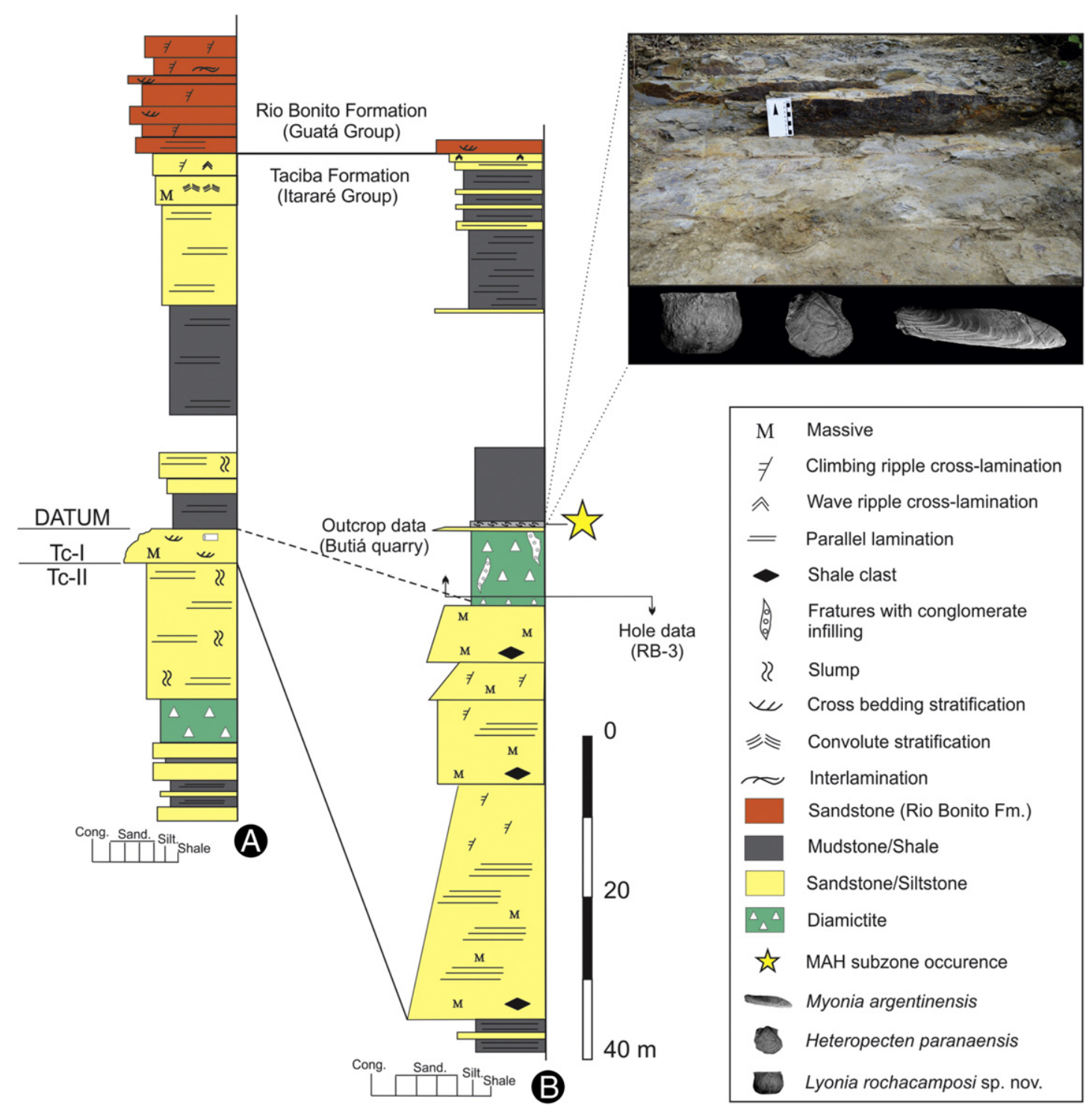

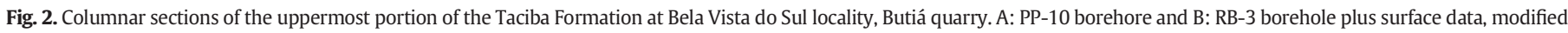
from Weinschutz and Castro (2006) and Neves et al. (2014b).

road between Ponta Grossa-Imbituva (see Lange, 1952, p. 82). This author described some brachiopods from that locality, which are also revised herein (see in Systematic Paleontology).

In Mafra County, rocks of the Taciba Formation are well exposed on the walls of abandoned quarries, such as the so-called Butiá quarry (Rocha Campos, 1966) at the margins of the eponymous river. Detailed subsurface stratigraphic data (cored wells) are also available
(Weinschutz and Castro, 2006). These data indicate that, locally, the Taciba Formation is represented by five meters of laminated siltstones and rithmites (= varvites) belonging to the glacial Taciba I sequence (sense Weinschutz and Castro, 2006). Above this, a 52.5 m-thick sandstone body occurs, which is succeeded by a $\sim 12$ m-thick grey diamictite that is itself overlaid by thin stratified conglomerate and sandstone beds. In ascending order these are succeeded by bioturbated,

Table 1

Summary of the main features of the studied lithofacies of the uppermost portion of the Taciba Formation, in the Teixeiras Soares and Bela Vista do Sul (Butiá) regions.

\begin{tabular}{|c|c|c|c|c|c|}
\hline Facies & Local Designation & Processes & Environment & Brachiopod species & n. \\
\hline $\begin{array}{l}\text { Parallel-laminated or } \\
\text { massive mudstones }\end{array}$ & Passinho Shale & $\begin{array}{l}\text { Deposition of background sediments from suspension under } \\
\text { low-energy conditions, in oxygen deficient, organic-rich bottoms, } \\
\text { below storm wave base }\end{array}$ & Outer shelf & $\begin{array}{l}\text { Biconvexiella roxoi } \\
\text { Quinquenella rionegrensis } \\
\text { Langella imbituvensis }\end{array}$ & $\begin{array}{l}2 \\
3 \\
1\end{array}$ \\
\hline Laminated siltstones & Baitaca Siltstone & $\begin{array}{l}\text { Low-energy, suspension fall-out deposition during fair-weather } \\
\text { periods punctuated by erosional events, as indicated by the splayed } \\
\text { valves of burrowing bivalves. Deposition above storm wave base }\end{array}$ & Inner to middle shelf & $\begin{array}{l}\text { ?Streptorhynchus sp. } \\
\text { ?Cyrtella sp. } \\
\text { Tomiopsis sp. cf. T. harringtoni } \\
\text { Biconvexiella roxoi } \\
\text { Quinquenella rionegrensis }\end{array}$ & $\begin{array}{l}1 \\
1 \\
1 \\
1 \\
2\end{array}$ \\
\hline $\begin{array}{l}\text { Highly bioturbated fine } \\
\text { sandstones }\end{array}$ & Butiá Sandstone & $\begin{array}{l}\text { Low-energy lower shoreface aerated bottoms. Sandstones may } \\
\text { record deposition from storms, with bioturbation recording } \\
\text { post-event periods. Deposition mostly above storm-wave base and } \\
\text { below fairweather-wave base. }\end{array}$ & Middle shelf & Lyonia rochacamposi sp. nov. & 106 \\
\hline
\end{tabular}




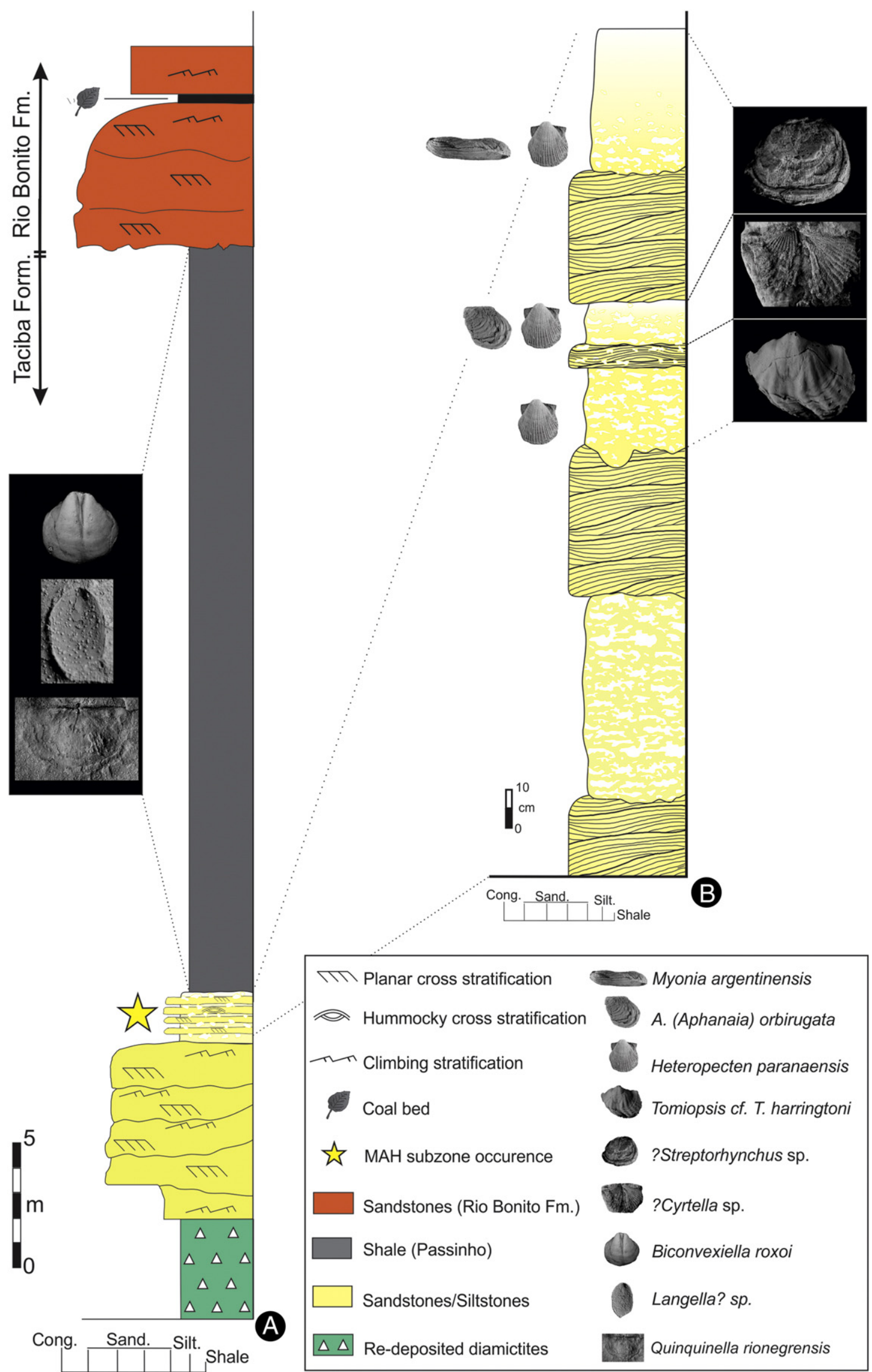

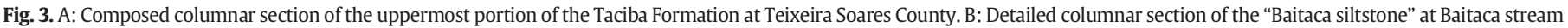
locality, where mostly of the studied brachiopods where collected (Modified from Neves et al., 2014b). 
Table 2

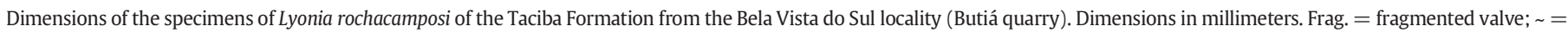
estimate.

\begin{tabular}{|c|c|c|c|c|c|c|}
\hline Specimen number & Maximum width & Hinge width & Dorsal length & Ventral length & Thickness & Costae number $/ 5 \mathrm{~mm}^{\mathrm{a}}$ \\
\hline CP.I 769 I & 50 & Frag. & 32 & - & - & 8 \\
\hline CP.I 763 & $\sim 38$ & $\sim 38$ & 29 & - & - & 12 \\
\hline CP.I 765 & $\sim 35$ & - & - & 17 & - & 10 \\
\hline CP.I 755 II & 37 & 36 & 27 & - & - & 10 \\
\hline CP.I 754 & 31 & $\sim 16$ & 28 & - & - & 9 \\
\hline CP.I 5011 & 40 & $\sim 32$ & 32 & - & - & 9 \\
\hline CP.I 2156 & 40 & 38 & & & - & 12 \\
\hline CP.I 769 II & $\sim 44$ & 42 & - & 37 & 12 & 9 \\
\hline CP. I 753 & $\sim 34$ & Frag. & - & $\sim 28$ & - & 8 \\
\hline СР. Е 4396B & $\sim 45$ & Frag. & - & 40 & - & 9 \\
\hline CP.E 536 & Frag. & 43 & - & $\sim 30$ & - & 11 \\
\hline DZP 18913 & 34 & 32 & 22 & - & 16 & 10 \\
\hline DZP 18906 & Frag. & 41 & - & $\sim 25$ & - & 12 \\
\hline DZP 19133B & 33 & 24 & 29 & - & - & 12 \\
\hline
\end{tabular}

a Costae number $/ 5 \mathrm{~mm}$ at middle portion of shell.

brachiopod-rich sandstones, which are in turn followed by dark shales (Weinschutz and Castro, 2006) (Fig. 2). This sandstone has also yielded mollusk shells, including both gastropods (Rocha Campos, 1966) and bivalves (Simões et al., 2012). All of these rocks are referred to the glacial succession of the Taciba II sequence (sense Weinschutz and Castro, 2006), which is succeeded locally by the Rio Bonito Formation (Weinschutz and Castro, 2006) (Fig. 2).

\section{The Eurydesma fauna}

4.1. The Taciba-Bonete Eurydesma faunal composition: an updated chrono-biocorrelation

The studied material from the uppermost section of the Taciba Formation exhibited significant, but low-diversity brachiopod assemblages, being monotypic in Bela Vista do Sul, where Lyonia rochacamposi sp. nov. is recognized in large numbers $\left(\sim 110 / \mathrm{m}^{2}\right)$, whereas the scarce fossil records in Texeira Soares include Biconvexiella roxoi (Oliveira, 1936),? Cyrtella sp., Langella imbituvensis (Oliveira, 1930), Quinquenella rionegrensis (Oliveira, 1930),? Streptorhynchus sp. and Tomiopsis sp. cf. T. harringtoni Archbold and Thomas, 1986 (see Table 4). These brachiopods co-occur in association with a more diverse bivalve fauna that was recently described by Simões et al. (2012) and Neves et al. (2014a, b). In total, six bivalve assemblages were identified, which are mainly dominated by four species: Heteropecten paranaensis Neves et al. (2014a), Atomodesma (Aphanaia) orbirugata (Harrington, 1955), Praeundulomya cf. P. subelongata Dickins, 1963 and Myonia argentinensis (Harrington, 1955) (see Plate I). These bivalves were demonstrated to be key species for establishing regional and interbasinal biocorrelations (Simões et al., 2012; Neves et al., 2014a, b). For example, Heteropecten paranaensis

Table 3

Dimensions of the brachiopod species of the Taciba Formation from Teixeira Soares and Imbituva counties. Dimensions in millimeters; = estimate.

\begin{tabular}{lccccc}
\hline $\begin{array}{l}\text { Specimen } \\
\text { number }\end{array}$ & $\begin{array}{l}\text { Dorsal } \\
\text { width }\end{array}$ & $\begin{array}{l}\text { Ventral } \\
\text { width }\end{array}$ & $\begin{array}{l}\text { Dorsal } \\
\text { length }\end{array}$ & $\begin{array}{l}\text { Ventral } \\
\text { length }\end{array}$ & Thickness \\
\hline GP-1E 2056 & 9 & & 6 & & - \\
GP-1E 4402 & - & 7 & - & 5 & - \\
GP-1E 4439 & 4 & - & 6 & - & - \\
GP-1E 4364 & - & 15 & - & $\sim 10$ & $\sim 3$ \\
GP-1E 4367 & - & 9 & - & 11 & $\sim 2$ \\
GP-1E 4437 & 9 & 9 & 6 & 6 & $\sim 4$ \\
GP-1E 4373 & $\sim 8$ & $\sim 10$ & $\sim 8$ & 5 & $\sim 4$ \\
GP-1E 4339a & - & 9 & - & 6 & - \\
GP-1E 4339b & 8 & - & 5 & - & - \\
DGM 4355 & 17 & - & $\sim 14,5$ & - & - \\
DZP 18829 & $\sim 26$ & $\sim 25$ & $\sim 20$ & $\sim 12$ & 7 \\
DZP 19139 & 6 & - & 4 & - & - \\
\hline
\end{tabular}

(Plate I, Figs. A-D) and Myonia argentinensis (Plate I Figs. K-M, O-P) are recorded in both deposits of the Itararé Group (Teixeira Soares and Bela Vista do Sul (Butiá quarry)) and in the Eurydesma fauna of the Bonete Formation (Sauce Grande-Colorado Basin, Argentina) (Neves et al., 2014a). The bivalve Atomodesma (Aphanaia) orbirugata (Harrington) (Plate I Figs. E-H) is also shared by the Taciba (Teixeira Soares) and Bonete formations, which provides even more support for this faunal affinity hypothesis.

The Eurydesma fauna in eastern Argentina was recorded in the lower half of the Bonete Formation through a stratigraphic section nearly 155 m-thick, although Eurydesma is notably absent in level 4 (=BM6), which is $15 \mathrm{~m}$-thick, located at 1285 to $1270 \mathrm{~m}$ above the base of the overlying Pillahuinco Group, $70 \mathrm{~m}$ above and $70 \mathrm{~m}$ below the first and last appearance of Eurydesma, respectively (Harrington, 1955). This fossil-bearing bed is characterized only by two brachiopods, Tivertonia pillahuincensis (Harrington, 1955) (= Chonetes pillahuincensis Harrington, 1955; Archbold and Gaetani, 1993; Pagani, 1998) and Tomiopsis harringtoni Archbold and Thomas, 1986 (=Notospirifer darwini (Morris) Harrington, 1955), and a diverse bivalve assemblage including Myonia argentinensis (Harrington, 1955) (= Stutchburia? argentinensis Harrington, 1955; Pagani, 2000; Simões et al., 2012), Exochorhynchus inflectoventris (Harrington, 1955) (Neves et al., 2014b; = Allorisma inflectoventris Harrington, 1955; Pagani, 2000), Atomodesma (Aphanaia) orbirugata (Harrington, 1955) (= Aphanaia? orbirugata Harrington, 1955; Pagani, 2000) and Leptodesma (Leiopteria) dutoiti (Harrington, 1955) (= Liopteria? dutoiti Harrington, 1955; Pagani, 2000). More recent fossil records from this stratigraphic interval (BM6) have added Deltopecten harringtoni Rocha Campos and de Carvalho, 1975, Vacunella camachoi Rocha Campos and de Carvalho, 1975, Promytilus acinaciformis Harrington, 1955 (Pagani, 2000) and Heteropecten paranaensis Neves et al., 2014a. This assemblage shares various genera (the bivalves Palaeoneilo, Phestia, Promytilus, Exochorhynchus and Schizodus) with those from Texeira Soares and Bela Vista do Sul as well as three three bivalve species Atomodesma (Aphanaia) orbirugata (Harrington), Myonia argentinensis (Harrington) and Heteropecten paranaensis Neves et al., 2014a. In addition a species remarkably similar to Leptodesma (Leiopteria) dutoiti (Harrington), referred as Leptodesma (Leiopteria) aff. dutoiti from Texeira Soares, was indicated by Neves et al. (2014b). Likewise, Tomiopsis cf. T. harringtoni Archbold and Thomas described herein reinforces the recognition of the Eurydesma fauna in the Paraná Basin, as postulated by Simões et al. (1998, 2012), Pagani (2000) and Neves et al. (2014a, b). Furthermore, this biocorrelation between the Bonete and Taciba formations is refined to a short interval within the recognized level 4 (BM6) of the Eurydesma Biozone (Dickins, 1985) by Harrington (1955) and the thin fossil-bearing beds $(<5 \mathrm{~m}$ ) of Texeira Soares and Bela Vista do Sul. The 


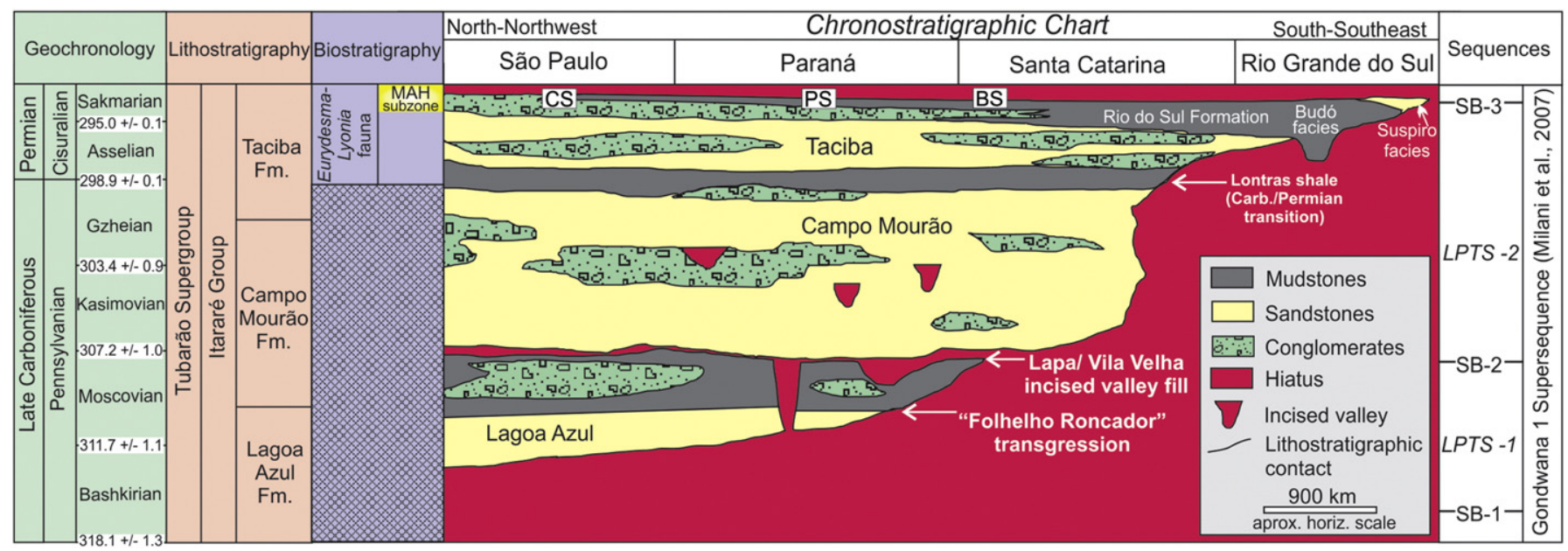

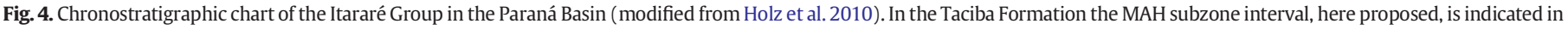
yellow. Explanation: CS = Capivari Shale; PS = Passinho Shale; BS = Butiá Shale.

absence of Eurydesma in these last stratigraphic intervals was explained by Neves et al. (2014b; see also Runnegar, 1979) as being due to ecological competition with Pachydomidae bivalves, especially Myonia, which can cause local extinction of Eurydesma populations. This same mechanism could also be valid for the Eurydesma-lacking fossilbearing level 4 (BM6) of the Bonete Formation in Argentina. The Myonia argentinensis-Atomodesma (Aphanaia) orbirugata-Heteropecten paranaensis association (MAH) is proposed here to recognize this regional stratigraphic interval, or Subzone, within the Biozone of Eurydesma. The MAH assemblage includes some bivalve species, such as Praeundulomya cf. subelongata Dickins, 1963 (Neves et al., 2014b) and Limipecten capivariensis (=Aviculopecten capivariensis Mendes, 1952) that are also recognized in the Capivari Formation (Simões et al., 2015) as well as Lyonia rochacamposi (classification by one of the authors: ACT), thus extending the boundary of the Eurydesma transgression northward to the northernmost Paraná Basin in São Paulo State.

Rocha Campos (1970) indicated the Bonete Formation as supraglacial, while the Taciba Formation is more closely associated with diamictite beds (Figs. 2 and 3). The first appearance of the Eurydesma fauna in the Bonete Formation occurs at its base, $300 \mathrm{~m}$ above (the entire Piedra Azul Formation) the glacial-related Sauce Grande Formation. This thick interval and another of $70 \mathrm{~m}$, that separates from MAH at the base of level 4 (BM6) of Harrington (1955) are absent in the upper section of the Taciba Formation, where MAH also occurs. This circumstance suggests a brief, but significant hiatus just above the diamictite interval of the Taciba Formation and a subsequent northward delay of the Eurydesma postglacial transgression (Fig. 5).

In the Sauce Grande Basin, SHRIMP radiogenic isotope dating of zircons in tuffs of the uppermost section of the Tunas Formation (500 m thick) provided an early Kungurian age of $280.8 \pm 1.9$ Ma for this unit (López Gamundi et al., 2013; see also Tohver et al., 2007, 2008 and Alessandretti et al., 2010), constraining the Eurydesma- bearing beds ( $700 \mathrm{~m}$ below) of the underlying Bonete Formation to pre-Kungurian times (after Cohen et al., 2013, the age of the base of the Kungurian is $283.5 \pm 0.6,4$ Ma older than the previous age of $279.3 \pm 0.5 \mathrm{Ma}$ indicated in the stratigraphic chart of Gradstein et al., 2012). In the Paraná Basin, U-Pb SHRIMP ages obtained from tonsteins interbedded in coal seams of the Rio Bonito Formation indicated a radiometric age of $291 \pm 1.2 \mathrm{Ma}$ (Simas et al., 2012, 2013; see also Matos et al., 2001; Guerra-Sommer et al., 2008a, b, c; Rocha Campos et al., 2006, 2007, 2011; Mori et al., 2012), constraining the Eurydesmabearing beds of the underlying Taciba Formation to pre-Artinskian (Neves et al., 2014b) or, more precisely, to pre-latest Sakmarian times, which is also valid for the coeval fauna of the Bonete Formation. Common genera, such as Eurydesma, Deltopecten, Lyonia and Tomiopsis as well as Praeundulomya cf. elongata Dickins, close species and possible Punctocyrtella, along with the relative bivalve diversity of the South American Eurydesma fauna, strongly suggest a coeval condition for the Eurydesma assemblage of the uppermost Lyons Group/Carrandibby Formation (Carnarvon Basin) of Western Australia. Collectivelly, faunal affinities of the Eurydesma-Lyonia fauna based in common records of genera mainly of bivalves (Eurydesma, Deltopecten, Praeundulomya and Astartila), brachiopods (Lyonia, Neilotreta, Punctocyrtella, Tomiopsis, Tivertonia, Biconvexiella) and gastropods (Peruvispira, Keenia), extend eastward the trans-gondwanan marine connection. This faunal linkage reinforces previous correlations to geographical areas that were adjacent or close to western Australia during Asselian-early Sakmarian times (Dickins and Shah, 1981, 1987; Shi and Archbold, 1993). Biocorrelation among the Lyons Group and Carrandibby Formation to Talchir, Umaria and Bap formations of India (Archbold et al., 1996, and references provided therein), Nilawan Group in Salt Range and the Agglomeratic Slate in Kashmir, Pakistan, eastern Himalaya (Waagen, 1881; Reed, 1936; Sahni and Srivastava, 1956; Dickins, 1985; Singh and Archbold, 1993) were suggested (Fig. 6). Comparable faunas to those of western Australia were also recognized even further east,

Table 4

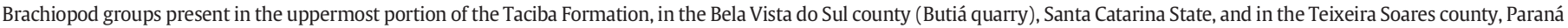
State.

\begin{tabular}{|c|c|c|c|c|c|}
\hline Locality & Order & Superfamily & Family & Genus & Species \\
\hline Bela Vista do Sul (SC) & Productida & Proboscidelloidea & Auriculispinidae & Lyonia & Lyonia rochacamposi sp. nov. \\
\hline \multirow{6}{*}{$\begin{array}{l}\text { Teixeira Soares } \\
\quad(\mathrm{PR})\end{array}$} & Orthotetida & Orthotetoidea & Schuchertellidae & Streptorhynchus & ?Streptorhynchus sp. \\
\hline & Spiriferinida & Syringothyridoidea & Syringothyrididae & Cyrtella & ?Cyrtella sp. \\
\hline & Spiriferida & Martinioidea & Ingelarellidae & Tomiopsis & Tomiopsis sp. cf. T. harringtoni \\
\hline & & Cyrtospiriferoidea & Ambocoeliidae & Biconvexiella & Biconvexiella roxoi \\
\hline & Chonetida & Chonetoidea & Rugosochonetidae & Quinquenella & Quinquenella rionegrensis \\
\hline & Lingulida & Linguloidea & Lingulidae & Langella & Langella imbituvensis \\
\hline
\end{tabular}



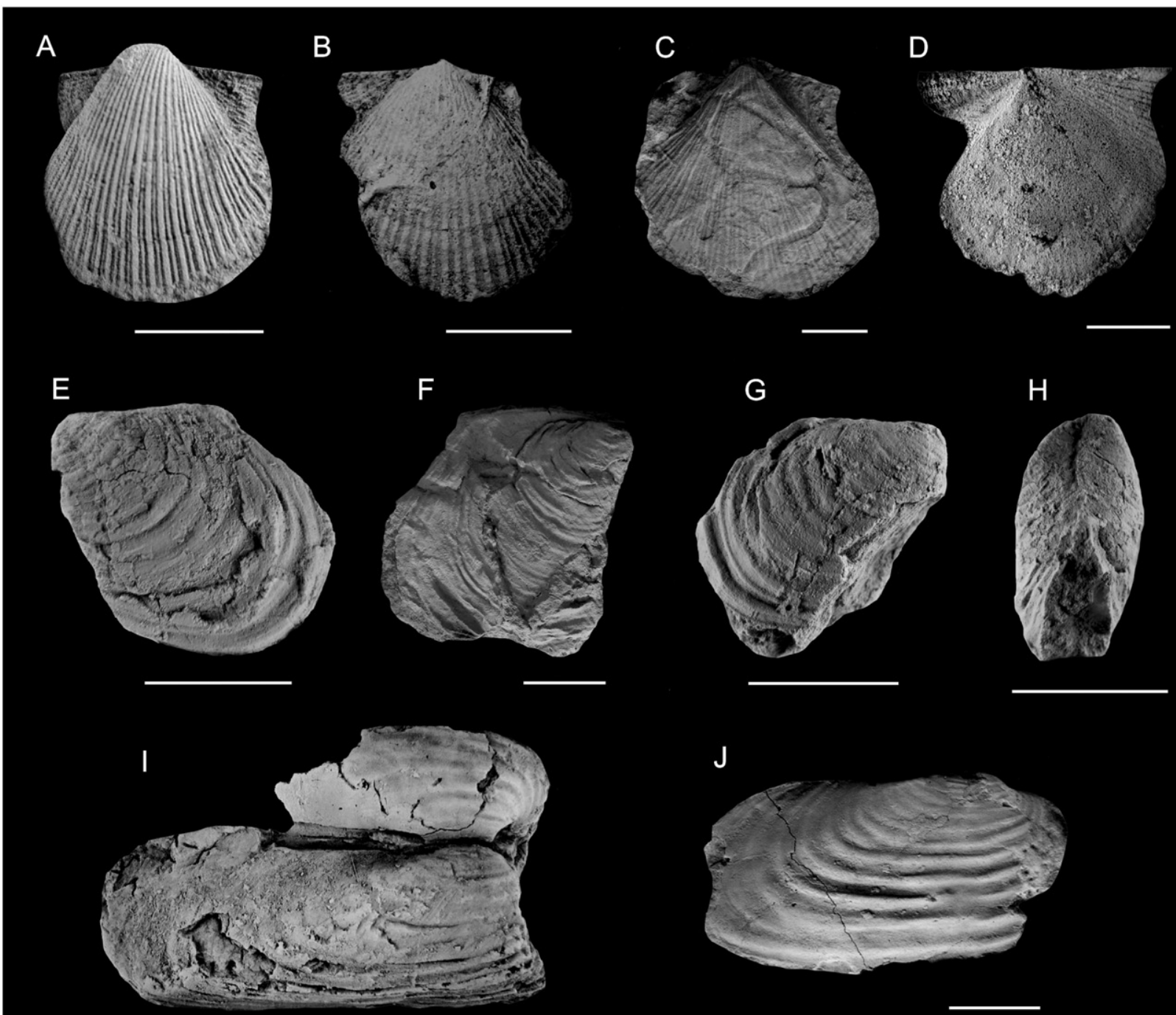

$\mathrm{K}$

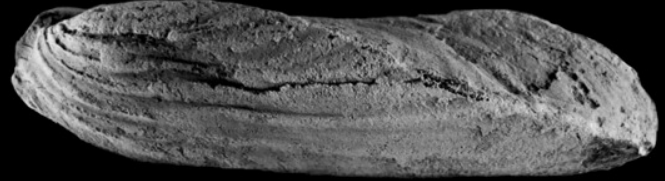

M

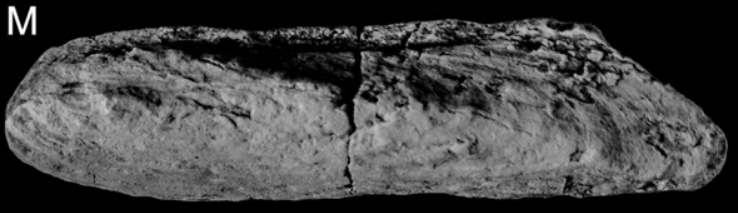

$\mathrm{L}$
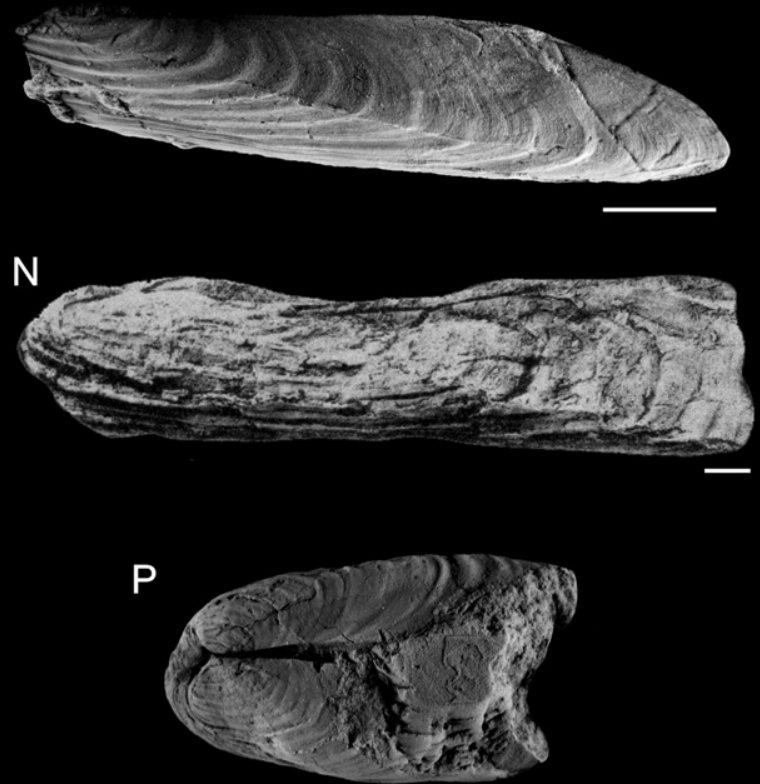

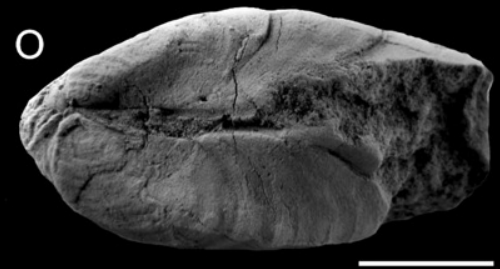




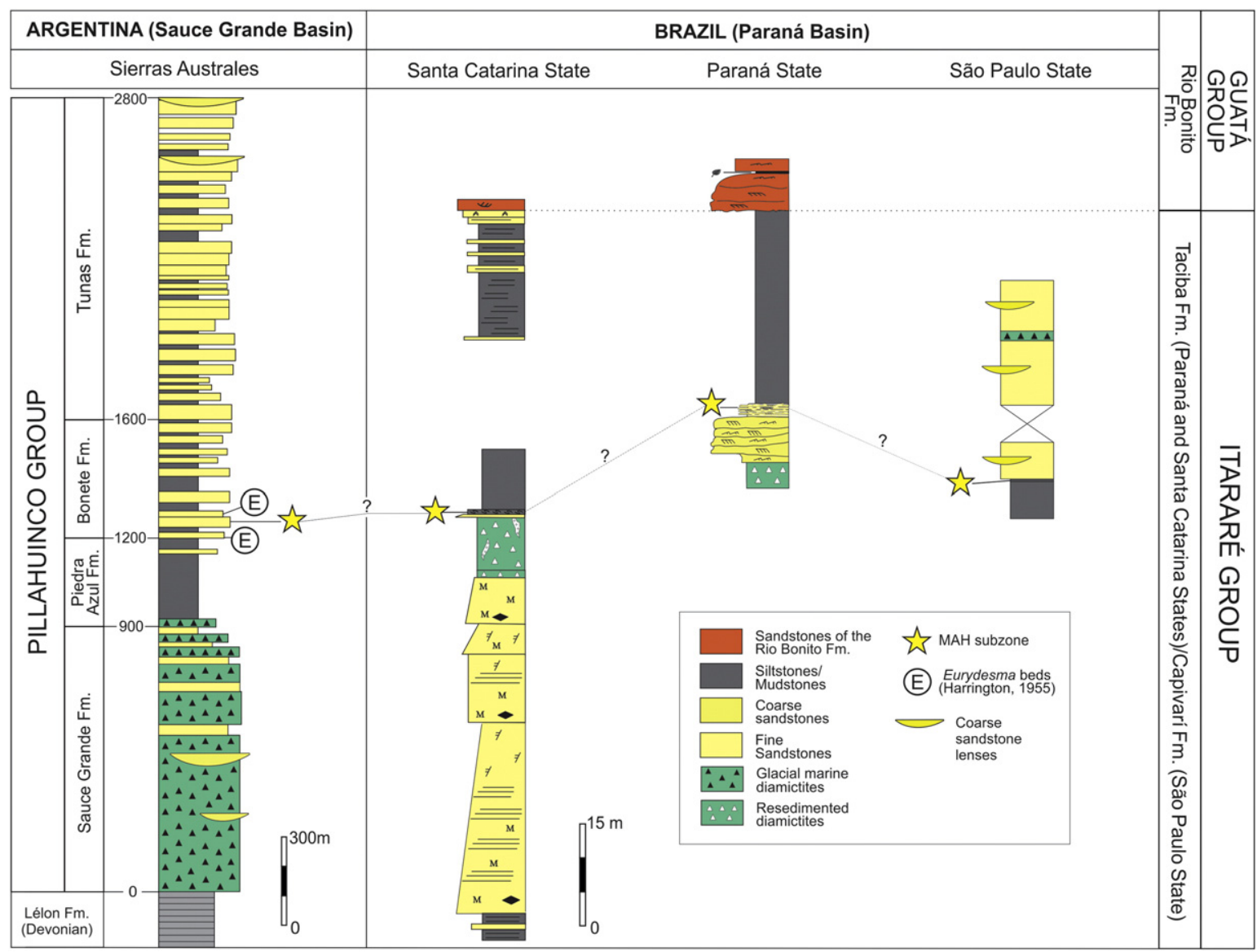

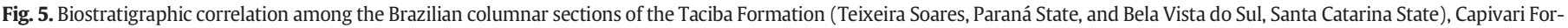
mation (homonymous county, São Paulo State), and Bonete Formation (Sierras Australes), in Argentina.

such as in Tibet of south China (Xinsheng, 1983), Malaysia (Shi et al., 1997), Western Yunnan (Shi et al., 1995, 1996), Irian Jaya (Archbold, 1982) and Timor (Archbold and Barkham, 1989; Archbold and Bird, 1989), in southeast Asia (Archbold, 2000; and references provided therein).

On the other hand, Cagliari et al. (2014) provided LA-ICP-MS U-Pb zircon age data, in parallel with the previous radiometric information mentioned above, which showed that deposition of the Rio Bonito Formation occurred between Sakmarian and Kungurian times, but suggesting the existence of significant hiatuses during its deposition. The period of time associated with such hiatuses suggests constraint deposition of the entire Itararé Group between Bashkirian-Moscovian times, contradicting absolute chronostratigraphy for most biochronology information (Cagliari et al., 2014) and significantly predating the age provided by marine fossil invertebrates in particular, including the Eurydesma fauna itself.

\subsection{The Eurydesma fauna of the Dwyka (SW Africa) and Lyons Groups (Western Australia)}

In western Gondwana, in addition to the South American Eurydesma faunal records, a poorly diversified Eurydesma assemblage was also recorded, interbedded within glaciomarine deposits of the Dwyka Group in Namibia (Aranos Basin), in southwest Africa (Dickins, 1961,
1985). In association with Eurydesma mytiloides Reed, 1932, the bivalve Atomodesma (Aphanaia) haibensis (Reed, 1936) and the gastropod Peruvispira vipersdorfensis Dickins, 1957 were described, while conulariids and fish remains were only mentioned (Reed, 1936; Martin and Wilczewski, 1970). The Eurydesma fauna occurs in a mudstone dropstone-rich to dropstone-free upward horizon with a maximum thickness of $76 \mathrm{~m}$, which corresponds to the Deglaciation sequence III (DS III) of the Dwyka Group, referred to as the Hardap shale Member by SACS (1980; Stollhofen et al., 2000, 2008). Zircon separated from a tuffaceous horizon of the Hardap shale Member revealed a refined ${ }^{206} \mathrm{~Pb} /{ }^{238} \mathrm{U}$ age of $297.1 \pm 1.8 \mathrm{Ma}$ age (see also Bangert et al., 1999; Stollhofen et al., 2000), which places the top of DS III in the early Permian Asselian Stage (Stollhofen et al., 2008). Although reevaluation using information preferably provided by ID-TIMS data would be desirable, this early Asselian age (base of the Asselian Stage at $298.9 \pm 0.15 \mathrm{Ma}$, according to the International Chronostratigraphic Chart of Cohen et al., 2013) could tentatively be taken as the oldest Eurydesma record. Its stratigraphic position, bounded below and above by glacial-related intervals, appears to be influenced by a higher paleolatitudinal location compared with the South American and Western Australian upward-free glacial influence, a circumstance that locally (Namibia) suggests a condensed stratigraphic interval where younger Eurydesma occurrences (latest Tastubian) are not represented or could be biased and might not reflect most records of the whole Eurydesma

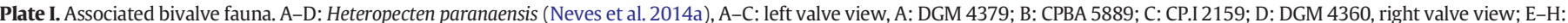

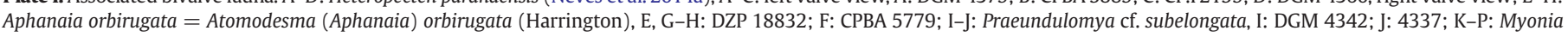

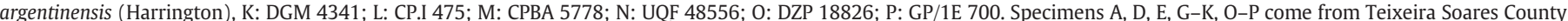

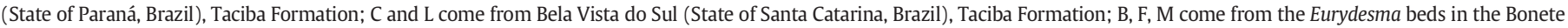
Formation, Eastern Argentina, and the specimen N comes from Queensland, Australia (Myonia or Vacunella? sp. of Runnegar, 1967, plate 4, fig. 16). Scale bar = 10 mm. 


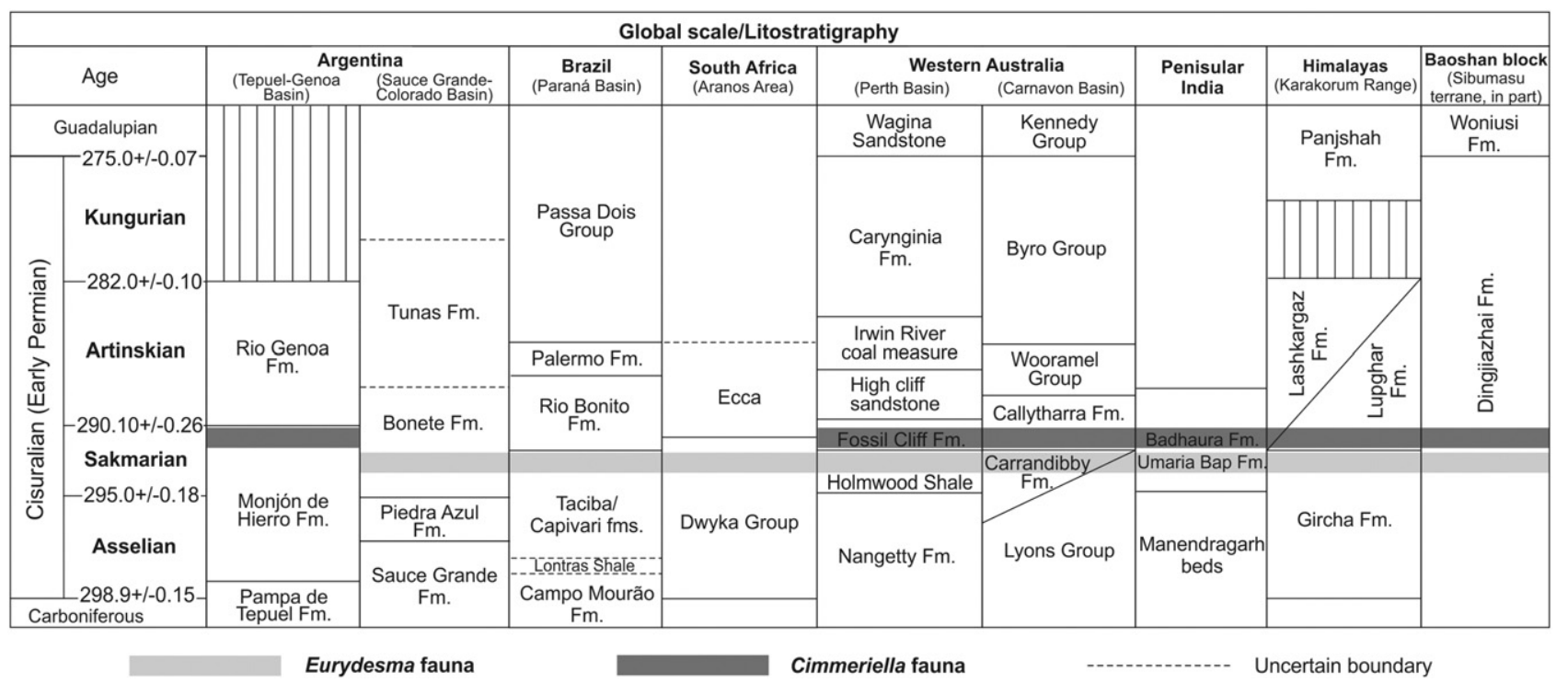

Fig. 6. Litostratigraphic correlation of the Eurydesma fauna across the W-E transgondwana marine connection.

transgression. Some authors have suggested this date as an important age calibration for the marked Eurydesma transgression reported Gondwana-wide, but this marine transgression continued upward in lower paleolatitudes, where glacial influence ceased earlier in more open marine basins (Bangert et al., 1999; Stollhofen et al., 2000, 2008). The Eurydesma-bearing Hardap shale Member is capped by the Deglaciation IV interval with a maximum thickness of $70 \mathrm{~m}$ and the top of the Dwyka Group in Namibia (Bangert et al., 1999; Stollhofen et al., 2000, 2008). The lower Gorge Tuff situated $1.6 \mathrm{~m}$ (basal Prince Albert Formation) above the Dwyka-Ecca boundary yielded a weighted mean ${ }^{206} \mathrm{~Pb} /{ }^{238} \mathrm{U}$ age of $290.9 \pm 1.7 \mathrm{Ma}$ (Werner, 2006), constraining the top of the glacial-related DS IV to near the Sakmarian-Artinskian boundary. Another glacial-related horizon estimated to show a Sakmarian-Artinskian age was indicated in the upper part of the Mojón de Hierro Formation (Tepuel-Genoa Basin) in southern Patagonia, Argentina, but was located at subpolar paleolatitudes during the Late Paleozoic Ice Age (Taboada, 2010, Pagani and Taboada, 2011; Taboada and Shi, 2011; Isbell et al., 2013). An interval with a thickness of nearly $400 \mathrm{~m}$ underlies this glacial-related horizon and yields a fossil-rich Cimmeriella fauna (Taboada and Pagani, 2010), which shares common brachiopod genera (e.g., Neilotreta, Spirelytha, Cimmeriella, Arctitreta) with the Callytharra Formation, a unit that lies conformably above the Lyons Group/Carrandibby Formation in the Carnarvon Basin, Western Australia. This could constitute indirect evidence that the Eurydesma-bearing interval bounded by DS III and DS IV in Namibia (Aranos Basin) represents only a partial and slightly older Eurydesma record compared with those from South America and Western Australia.

In western Australia (eastern Gondwana), the Eurydesma fauna was recorded throughout the upper part of the glacial-related Lyons Group and the postglacial Carrandibby Formation (still with scattered glacial erratics: Mory and Haig, 2011), Carnarvon Basin, Western Australia. The age of this interval bearing the Eurydesma fauna is constrained by superpositional locations below the ammonoid Juresanites jacksoni (Etheridge, 1907) and Uraloceras irwinense (Teichert and Glenister, 1952) occurrences that are estimated to be late Sakmarian in age (Leonova, 1999, 2011; Archbold, 1999, 2001; Haig et al., 2014). The well-established transitional stratigraphic relationship (Hocking, 1990; Crostella, 1995; Mory and Backhouse, 1997; Mory et al., 2008) between the Carrandibby Formation (Byro Subbasin), bearing the uppermost Eurydesma occurrences, and the Callytharra Formation, with a relatively diversified fauna and incoming elements with Tethyan affinities (Dickins and Thomas, 1959), reinforces the above-suggested diachronic condition with this youngest Eurydesma record and that from the Hardap shale Member in Namibia. Archbold (1993) proposed two brachiopod biozones characterizing the upper Lyons Group and Carrandibby Formation (formerly Stage A of Dickins, 1963, nearly 1500 m thick; Skwarko, 1993), referred to as the Lyonia lyoni and Neilotreta occidentalis (formerly Trigonotreta occidentalis; see Waterhouse, 2008; Taboada et al., 2015) zones. The Lyonia lyoni Zone grouped fossil localities from low and middle stratigraphic records of the Lyons Group. It is characterized by the brachiopods Rhynchopora australassica Archbold, 1995 (Rhynchonellacea gen. Indet. Dickins and Thomas, 1959; see also Archbold and Hogeboom, 2000), Kiangsiella sp. Thomas, 1958 (=Kiangsiella Dickins and Thomas, 1959), Tomiopsis notoplicatus Archbold and Thomas, 1986, Punctocyrtella australis (Thomas, 1971) (=Pseudosyrinx sp. Dickins and Thomas, 1959), Trigonotreta lyonsensis Archbold and Thomas, 1986 (= Neospirifer sp. and Neospirifer sp. Dickins and Thomas, 1959; see also Angiolini et al., 2005, 2009) and the bivalve Deltopecten lyonsensis Dickins, 1957 (see also Skwarko, 1993). The top of the Lyonia lyoni Zone was defined by the incoming of Neilotreta occidentalis and Eurydesma playfordi Dickins, 1957 (Archbold, 1993), although the exact stratigraphic position of their incoming is unknown (localities ML105-ML110 and T23-T27 in the upper part of the Lyons Group in the Lyndon River area: Dickins and Thomas, 1959). Most of the species (Lyonia lyoni, Punctocyrtella australis, Trigonotreta lyonsensis, Tomiopsis notoplicatus and Deltopecten lyonsensis) that were first recognized in the preceding biozone persist throughout the Neilotreta occidentalis Zone (Dickins, 1957; Dickins and Thomas, 1959; Archbold, 1993; Skwarko, 1993). Furthermore, numerous bivalves and gastropods are added in this biozone, such as Schizodus crespinae Dickins, 1957, Astartila condoni Dickins, 1957, Peruvispira umariensis (Reed, 1928), Keenia carnarvonensis Dickins, 1957, Mourlonia (Mourlonia) lyndonensis Dickins, 1957, Stutchburia variabilis Dickins, 1957, Phestia lyonsensis (Dickins, 1956), Aviculopecten tenuicollis (Dana, 1847), Astartilla? oscura Dickins, 1957, Pachymyonia occidentalis Dickins, 1957, Praeundulomya elongata Dickins, 1957, Leiopteria? carrandibbiensis Dickins, 1957, Chaenomya? nuraensis Dickins, 1963 and Phestia darwini (Koninck, 1877), among others (Dickins, 1956, 1957, 1963). This diversity of mollusks, specially bivalves, typifies the upper section of the Neilotreta occidentalis Zone as well as the younger terms of the Eurydesma fauna in Western Australia. An early Sakmarian or more likely an earliest Sakmarian age is here reinforced to the uppermost section of the Lyons Group and Carrandibby Formation, while an Asselian age can be expected for the lower faunal record in the Lyonia lyoni Zone, as indicated previously 
by various authors (Dickins, 1957, 1963; Dickins and Thomas, 1959; Archbold, 1993; Stephenson, 2009; Taboada et al., 2015). Although a lower Eurydesma record is lacking within the Lyonia lyoni Zone, it can be expected.

\subsubsection{The age of the long-lived Eurydesma fauna}

The age of the whole Eurydesma fauna probably spans the earliest Asselian-Kungurian, but its older interglacial (SW Africa) or postglacial occurrences (South America and Western Australia towards the Cimmerian region) typified a mainly early Asselian-early Gondwanawide transgression by a major postglacial eustatic rise in sea-level (Dickins and Thomas, 1959; Dickins, 1997), leading to the collapse of the mains Gondwana Ice Sheets (Veevers and Powell, 1987). Although only a transient retraction of the subpolar ice caps would be expected, (a) Sakmarian-Artinskian glacial-related horizon in South Africa, (b) striated lonestones in the lower Permian coal measures in Victoria Land, Antarctica, (c) ice-rafted debris and diamictites in eastern Australia and Tasmania (Isbell et al., 2013; and references therein), and (d) diamictites and ice-rafted debris in Patagonia are observed.

This early Permian Eurydesma transgression is well documented in Western Gondwana through the Bonete (Sauce Grande-Colorado Basin) and Taciba (Paraná Basin) formations in SE South America and the Hardap shale Member (Aranos Basin) in SW Africa, while in NE Gondwana, it is represented in the upper Lyons Group/Carrandibby Formation (Carnarvon Basin and correlatable units of neighboring basins) as well as peninsular India and beyond, toward the Cimmerian region (Dickins and Thomas, 1959; Archbold, 1998, 2000; among others). Moreover, Eurydesma developed successfully in eastern Australia, SE Gondwana, until Kungurian times due to persistent cold paleoclimatic conditions (Dickins, 1978).

\subsection{The faunas preceding the Eurydesma fauna: the Lontras shale assemblage and correlatives}

On the eastern border of the Paraná Basin, the diamictite interval (Chapéu do Sol Member by França and Potter, 1988) underlying the Eurydesma fauna covers the upper part of the Campo Mourão Formation or Lontras shale (Weinschutz and Castro, 2006). The >100 m-thick Lontras shale (Andrade, 2010) consists of thin varved shales with dropstones overlain by bioturbated siltstones, fossiliferous black shales with abundant concretions and shaly rhythmites at the top (Hamel, 2005). It yields a rich fossil metric interval (Campáleo outcrop) of immense significance for establishing a relative age constrained below the Eurydesma fauna. The main fossils consist of sponges, actinopterygian fishes, bivalves, coelacanth scales, coprolites, conodonts, brachiopods, insects, scolecodonts, shark teeth, and fragments of wood (Mouro et al., 2014; and references provided therein). Wilner (2014) assigned the conodont remains to Mesogondelella spp., a cold-water tolerant genus (Kozur, 1998; Henderson and Mei, 2000) that is also present in younger strata of the Canning Basin in Western Australia (Nicoll and Metcalfe, 1998; Haig et al., 2014). Although purely speculative at this time, a possible link to the short-lived warming spike thermal event reported from the latest Carboniferous in high paleolatitudes of Siberia and Gondwanic deposits of Timor should be investigated (Davydov et al., 2013; Davydov and Biakov, 2015). Among the fossil remains of the Lontras shale, the sponge Microhemidiscia greinerti Mouro et al. (2014) is of particular biochronological significance; this species is comparable to Microhemidiscia ortmanni Kling and Reif, 1969 from the San Gregorio Formation, southern Paraná Basin, Uruguay (Mouro et al., 2014). Based on Holz et al. (2010), these authors assigned an Asselian-Sakmarian age to the fossil assemblages of the Lontras shale, although these authors mixed the paleontological contents of the Lontras shale and the Taciba Formation, where the latter unit bears the Eurydesma fauna and provides the reason for this age. A preliminary revision of brachiopods from the Lontras shale indicates the presence of Biconvexiella sp., Quinquenella sp. and Langella imbituvensis, which are taxa that are also recorded in the Taciba Formation; thus, a faunal affinity can be appreciated. Nevertheless, a record of the sponge Microhemidiscia in the San Gregorio Formation as well, among other fossil remains (summarized in Sprechmann et al., 2001) from shales of a marine intercalation between glacial deposits, suggests that its biocorrelation is more likely.

Furthermore, a probable counterpart of the Lontras shale/San Gregorio Formation is the Ganigobis shale Member of the Dwyka Group (Aranos Basin) in Namibia, southwest Africa (see also Werner, 2006). The $45 \mathrm{~m}$-thick, black dropstone-bearing to dropstone-free Ganigobis shale also yields a diverse fauna (mostly non described) of bivalves, fishes, asteroideans, gastropods, brachiopods, sponges, echinoids, crinoids, foraminifera, radiolaria, and cephalopods (Stollhofen et al., 2000, and references provided therein). Tuffs interbedded in the Ganigobis shale Member dated via SHRIMP reveal ages of $302.3 \pm$ $2.1 \mathrm{Ma}, 302.0 \pm 3.0$ and $299.5 \pm 3.1 \mathrm{Ma}$ (Stollhofen et al., 2008), corresponding to the latest Gzhelian, close to the Carboniferous-Permian boundary. These ages coupled with the faunal assemblages from the Ganigobis shale Member as well as the Lontras shale constrain the younger Eurydesma fauna to post-Gzhelian times.

\section{The paleobiogeographic scenario of the $\mathrm{W}-\mathrm{E}$ trans-Gondwana transient marine connection}

The western-eastern Gondwana Eurydesma faunas collectively exhibit Indoralian Paratinan/Westralian/Austrazean paleobiogeographical links (Archbold, 1983a, Shi and Archbold, 1993), as previously documented and reinforced herein based on new common taxa. Faunal exchange through shallow marine seaways between these regions (Dickins and Thomas, 1959; Shi and Archbold, 1993; Archbold et al., 1996) would have been possible, favored by a major glacioeustatic sea-level rise (Dickins, 1997). Estimates of the magnitude of glacioeustasy during the late Paleozoic can vary sharply, although an average variation in sea level of $\sim 120 \mathrm{~m}$ was suggested for the late Pennsylvanian-mid-Sakmarian span (Isbell et al., 2003; Rygel et al., 2008; Shi and Waterhouse, 2010), and a maximum fluctuation of $250 \mathrm{~m}$ could have occurred (Bates and Lyons, 2006). Within the Itararé Group, a $100 \mathrm{~m}$ sea-level fluctuation was documented in the so-called Lapa Sandstone in the southern Paraná Basin. The Lapa Sandstone has been interpreted as a channel-lobe system within a huge incised valley excavated during a sea-level lowstand at the end of the Carboniferous that was filled by sands from glacial outwashing during subsequent transgression (França et al., 1996; Holz et al., 2008). Nevertheless, even twice or three times this sea-level rise would appear to be insufficient to surpass thousands of kilometers of continental barriers (the landmass of Africa-India-Antarctica-Western Australia) intervening between the western and eastern Gondwana shorelines. An alternative mechanism must be coupled with the sealevel rise that allowed the Eurydesma fauna to be carried across the shallow seas of both the western and eastern sides of Gondwana.

It has been suggested a V-shaped proto-rift system through two major axes of extensional basin development formed via a northnorthwesterly trending axis paralleling the future South Atlantic and a broadly north-northeasterly trending line of separation related to the future Indian Ocean (Stollhofen et al., 2000, 2008) (see Fig. 7). Alongside the former axis, the Sauce Grande-Colorado Basin was located westward and the de Aranos Basin northeastward. In the middle, the recently characterized offshore Hesperides Basin connecting northward to the Paraná Basin and southward to the Kalahari and Karoo basins, among others, in a huge depositional area of near $3.000 .000 \mathrm{~km}^{2}$, with a Pennsylvanian-Triassic pile of up $7000 \mathrm{~m}$ in thickness (Pángaro and Ramos, 2015). Within this pile, facies of the Eurydesma transgression was seismically identified where the unconformity's amplitude reached minimum values, based on data from Argentinean offshore wells, extending southward until the Karro Basin (Pángaro and Ramos, 2015). The second axis coincides more closely with a tight continental fit between east Africa-India-west Antarctica-west Australia, with an 


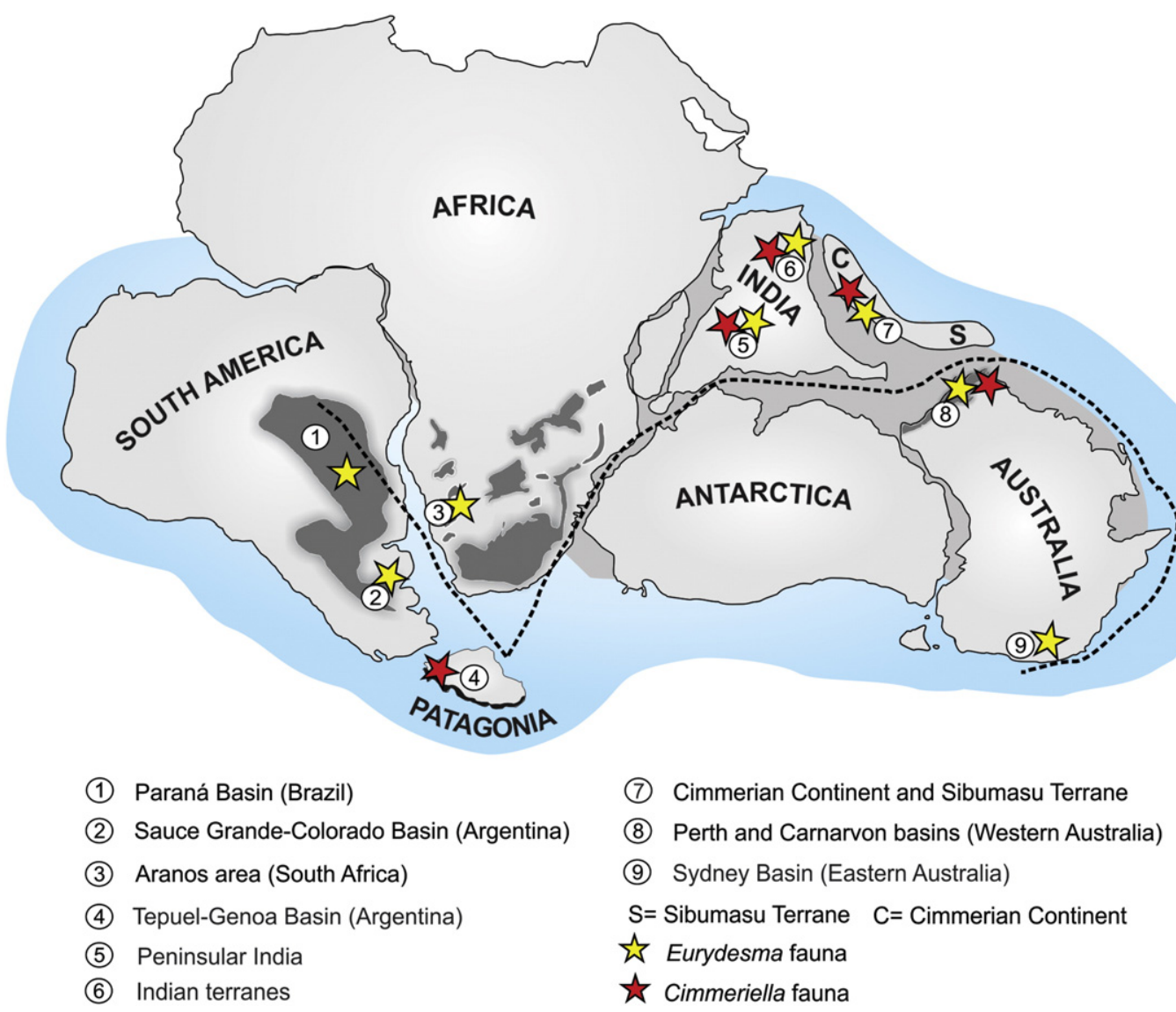

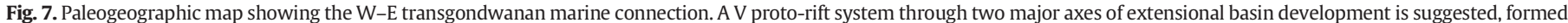
by a north-northwesterly trending axis paralleling the future South Atlantic and a broadly north-northeasterly trending line of separation related to the future Indian Ocean.

accommodation zone consisting of a wide intracontinental rift that extended from Australia's Northwest Shelf, between India and Antarctica, to southern Africa (Harrowfield et al., 2005). This rift was compartmentalized over a length scale of $\sim 650 \mathrm{~km}$, corresponding to accommodation zones, margin-normal geophysical lineaments, and long-lived crustal weaknesses, collecting Gondwana's thick PermianTriassic sedimentary deposits (Harrowfield et al., 2005), in a similar manner to the Hesperides Basin. The Eurydesma transgression would have progressed throughout this proto-rift system through a long narrow shallow seaway, allowing faunal exchange between east and west Gondwana. The vertex of this V-shaped proto-rift system and the seaway passage of the Eurydesma transgression would have been located between the South Africa-Malvinas/Falklands-Agulhas plateau and the Antarctic detached southern Patagonia (Deseado Massif) (Ramos and
Naipauer, 2014) before its collision with South Africa (Lindeque et al. 2011) and the pre-drifted Ellsworth mountain terrane (Elliot et al., 2014).

Central-eastern Peninsular India subsidiary linear rift basins, such as the Koel-Damodar, Son-Mahanadi, Pranhita-Godavari and Satpura basins (Casshyap and Tewari, 1987; Wopfner and Casshyap, 1997; Ghosh, 2003), to the eastern branch of the main proto-rift system would document the marine incursion of the Eurydesma transgression through this via. This Carboniferous-Permian intracontinental rift system continues northeastward to western Australia including the Perth, Carnarvon and Canning basins (Biswas, 1999; Cawood and Nemchin, 2000; Harrowfield et al., 2005), where early Permian marine faunas, particularly the Eurydesma-Lyonia fauna, occur profusely. As was mentioned above, the Eurydesma-Lyonia faunal affinities extend

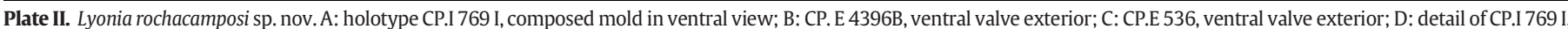

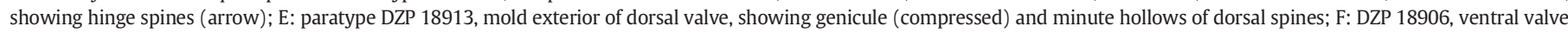

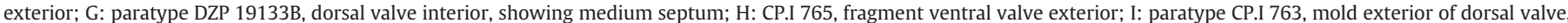

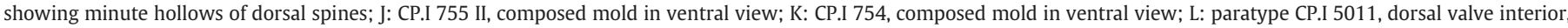

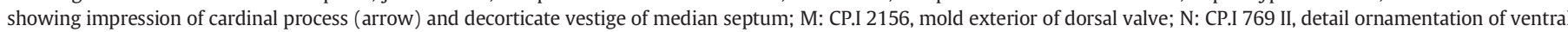
valve; O: CP. I 753, detail ornamentation of ventral valve. Scale bar $=10 \mathrm{~mm}$.

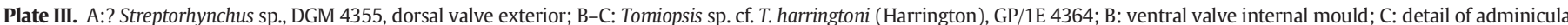

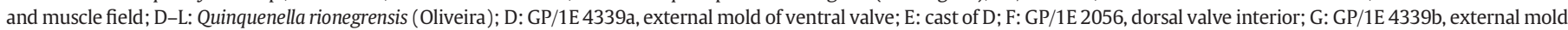

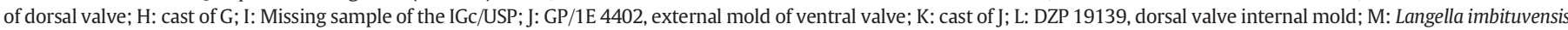

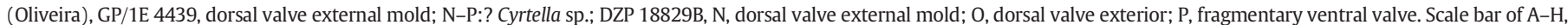
$\mathrm{N}-\mathrm{P}=10 \mathrm{~mm}$; scale bar $\mathrm{J}-\mathrm{M}=5 \mathrm{~mm}$. (see on page 444 )

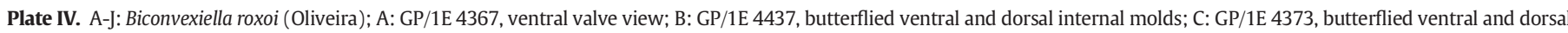

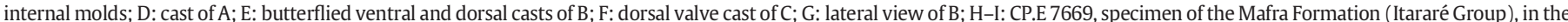

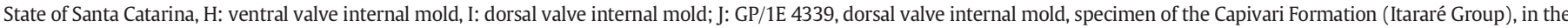

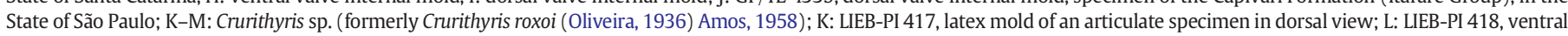
valve internal mold; M: LIEB-PI 419, dorsal valve internal mold. Scale bar of A-F, H-M $=10 \mathrm{~mm}$, scale bar of G $=5 \mathrm{~mm}$. (see on page 445 ) 


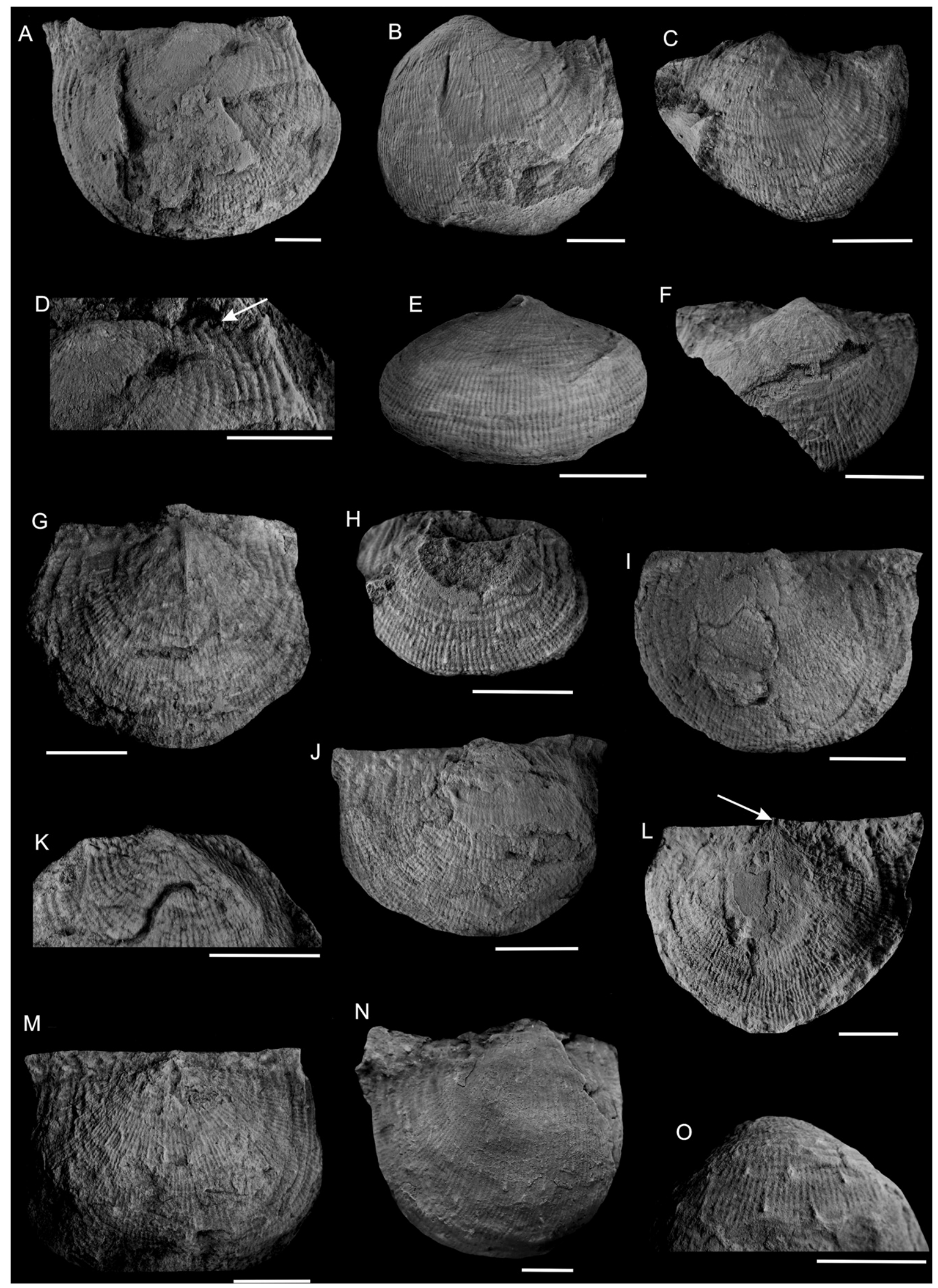



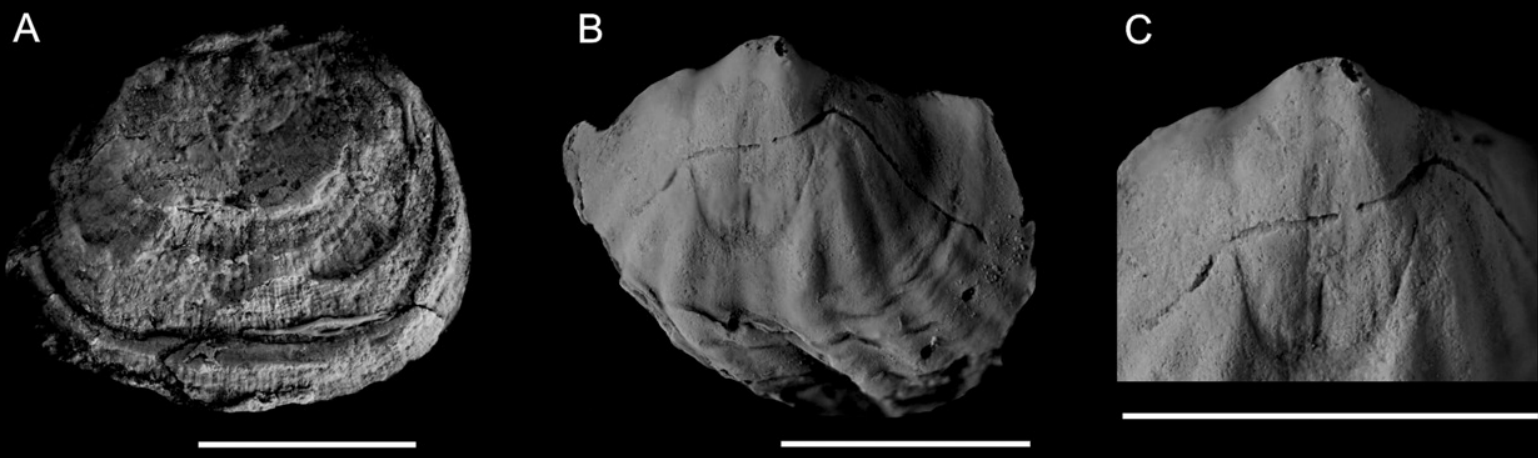

D
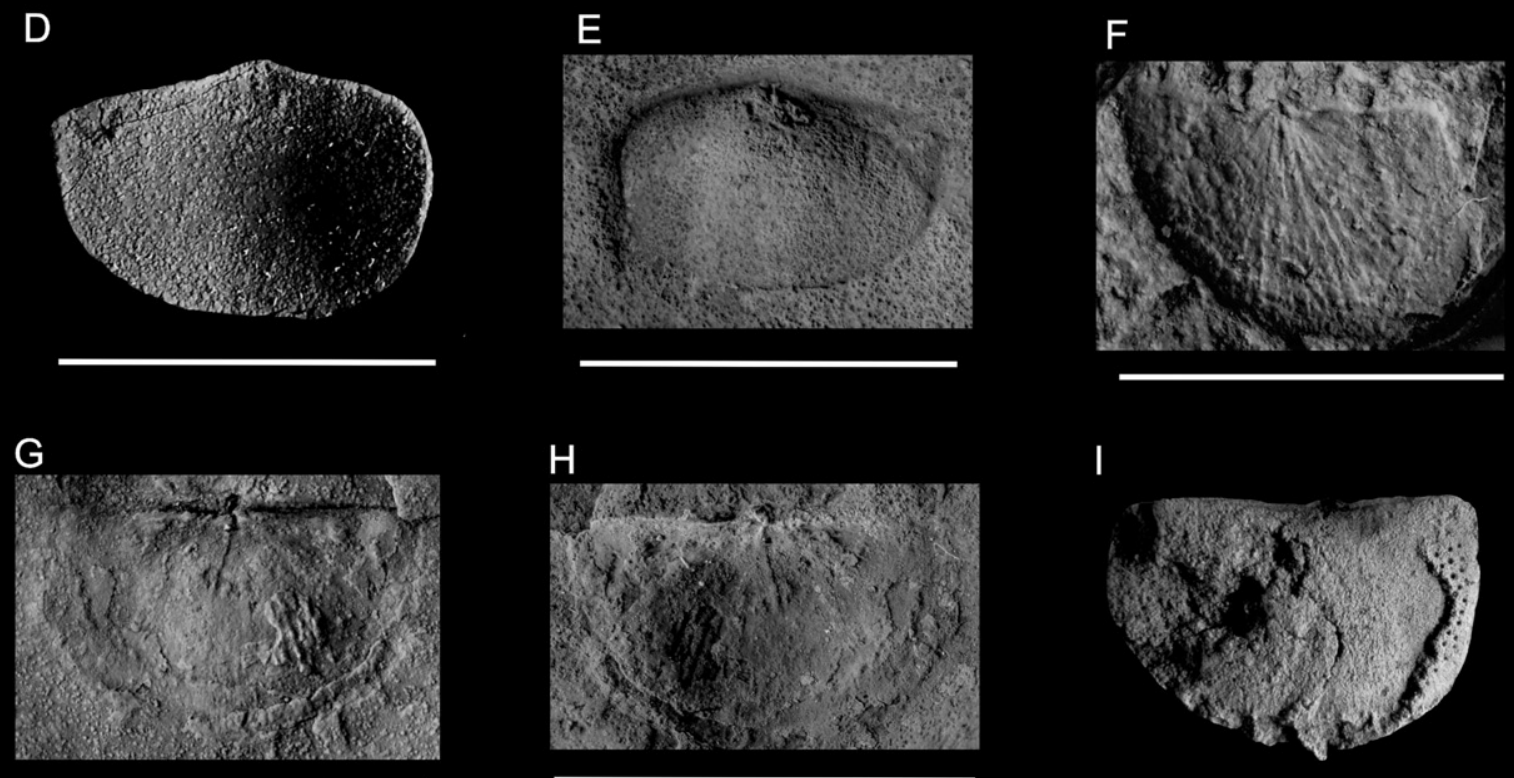

$\mathrm{H}$

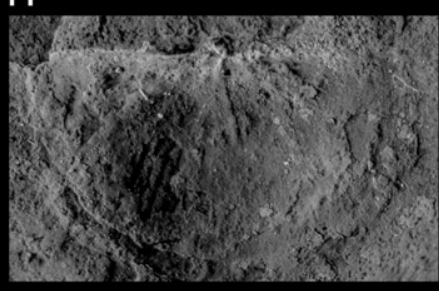

I
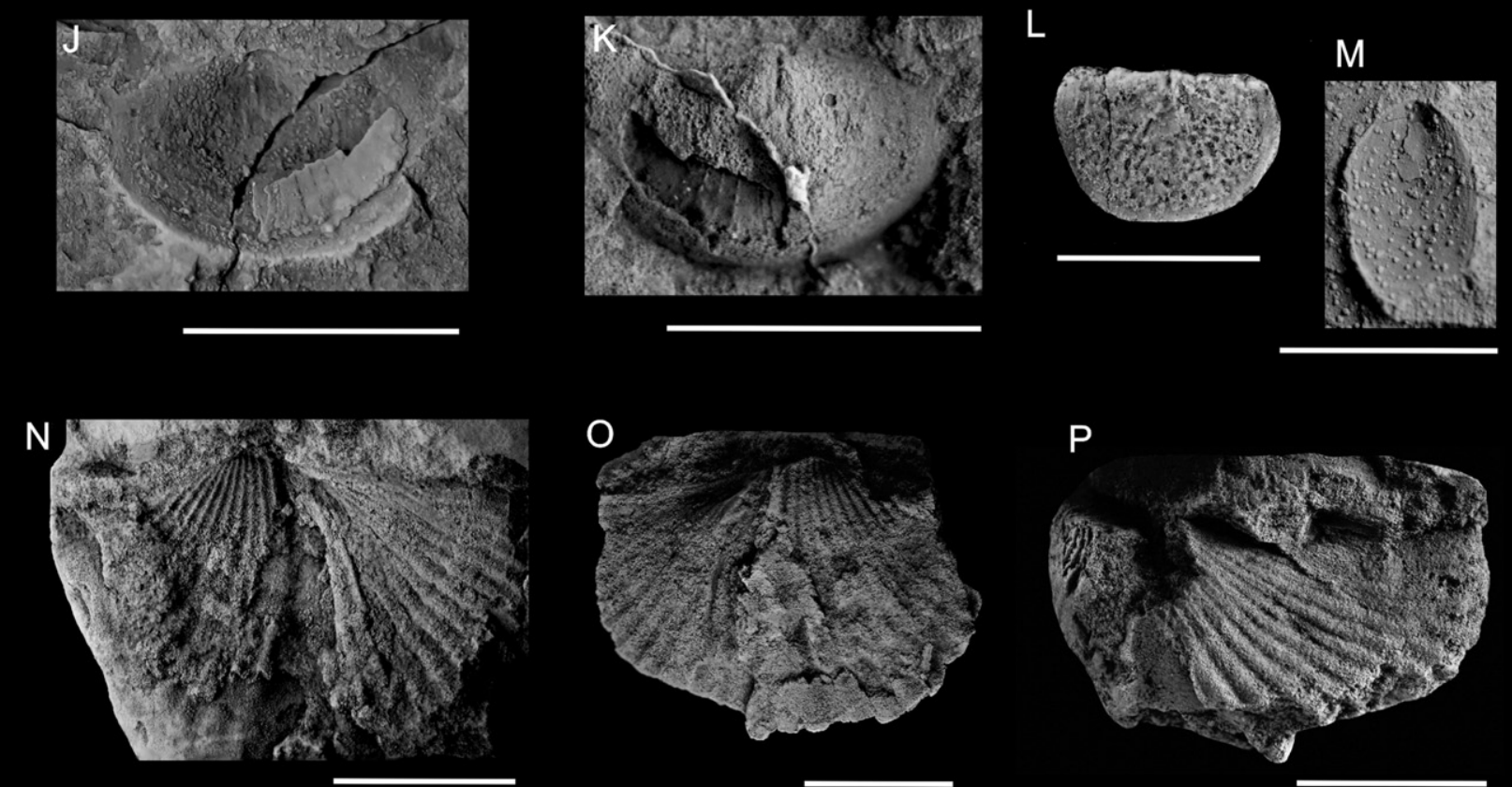

$\mathbf{P}$

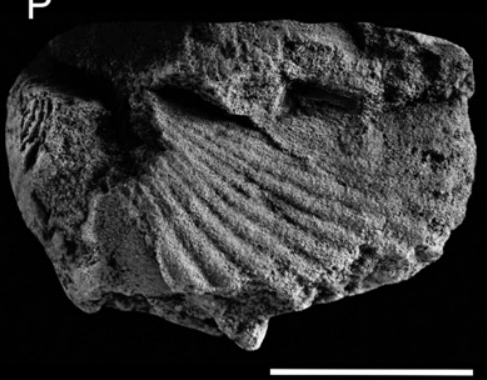

Plate III (caption on page 442). 


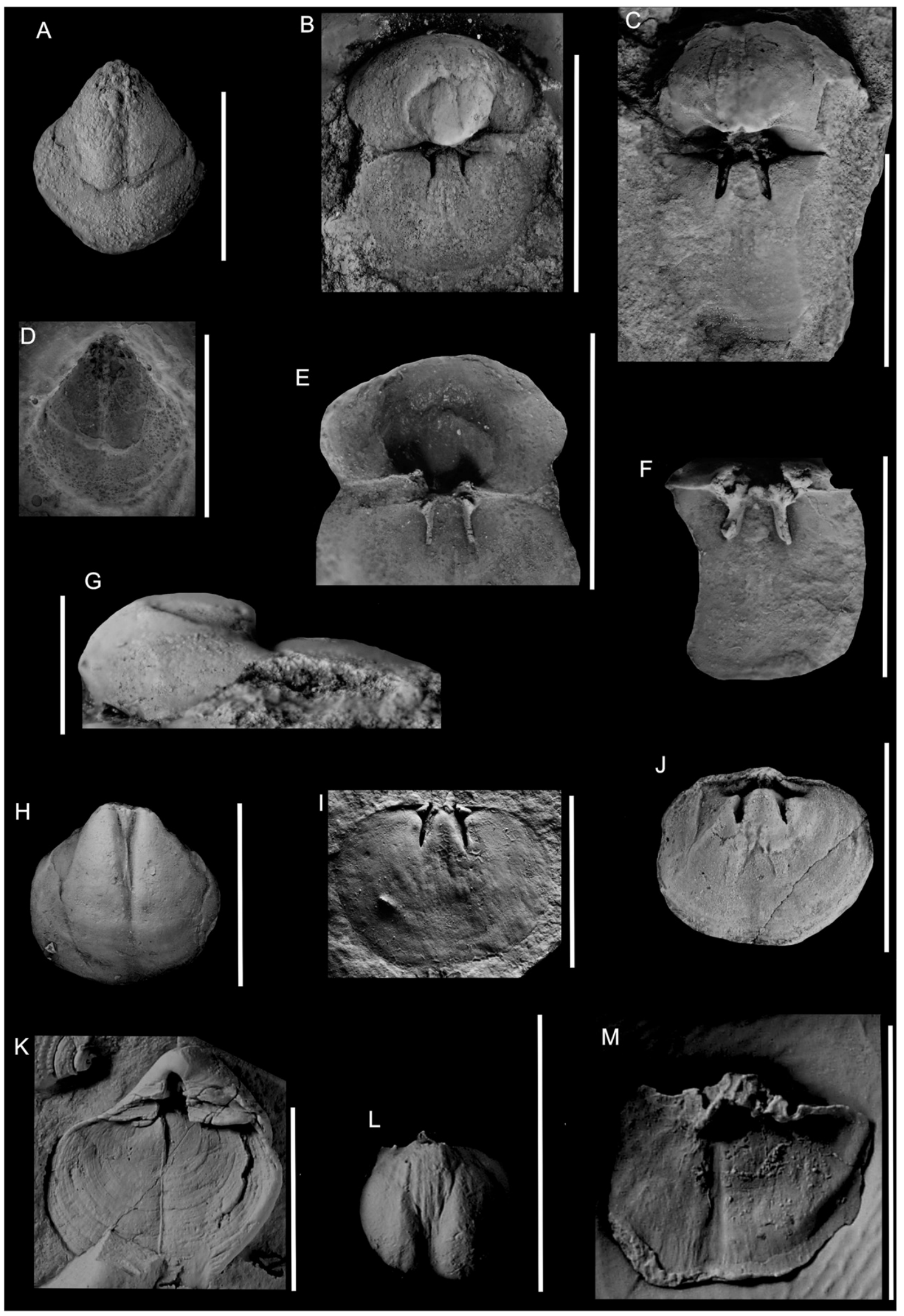

Plate IV (caption on page 442). 
the transgondwanan marine connection to geographical areas that were adjacent or close to western Australia- Peninsular India during Asselian-early Sakmarian times. During this time interval, a narrow and elongate continental assembled microcontinents grouped into the Cimmerian Continent (Sengör, 1979) was close to northern Gondwana (Fig. 7). The Cimmerian Continent was composed of small pieces of continental fragments distributed from present-day Turkey to Sumatra through Transcaucasia, Central Iran, South Afghanistan, South Pamir, Karakoram, Tibet, West Yunnan, the Shan State of Burma, western and Peninsular Thailand, and western Peninsular Malaysia (Sengör, 1979, 1984; Metcalfe, 1996, 1999, 2002; Ueno, 2003; Angiolini et al., 2013; Zhang et al., 2013). Close Gondwana faunal affinities based on brachiopods from some blocks of the Cimmerian Continent such as the Sibumasu terrane, as well as others from independent blocks such as Lhasa, Bijni tectonic unit, south and central Tibet ("Himalayan terranes"), and Peninsular India and Carnarvon Basin, among others, allowed recognize the Indolarian faunal province by Shi and Archbold $(1993,1996)$ (see also Shen et al., 2013). The Indolarian faunal province was possibly over $50^{\circ}-60^{\circ} \mathrm{S}$, as indicated by low taxonomy diversity, a characteristic coldwater bivalve fauna (Eurydesma and Deltopecten, among others), and glacial deposits. Furthermore, Shi and Archbold (1993) anticipated the assignation of the Eurydesma fauna from the Paraná (Brazil) and Sauce Grande basins (Argentina) within the Indolarian province. The central-eastern Indolarian fauna (Asselian-early Sakmarian) characterized the domain of the Khsir Sagar sea, limited northward by the eastern Cimmerian Continent (Sibumasu block), westward by the Paleotethys ocean and stretching southward to Peninsular India (Kapoor and Maheshwari, 1991; see also Kapoor et al., 1992 and Dickins, 2000) and western Gondwana through the narrow rift-system net. The Khsir Sagar sea domain expanded with the incoming of the Cimmeriella fauna (formerly Stepanoviella or Globiella faunas) during the late Sakmarian (Kapoor and Maheshwari, 1991). This expansion linked to a widespread record of the brachiopod Cimmeriella, being recognized in Western Australia, India and the Cimmerian Continent, sometimes coupled with the Eurydesma fauna. This fauna was interpreted as evidence of a cold-temperate faunal association linked to a general trend towards paleoclimatic amelioration (Waterhouse, 1970; Archbold et al., 1993; Dickins et al., 1993; Shi and Archbold, 1993, 1996). A complete analysis of Gondwanan, early Permian correlations of this time interval was offered by Archbold $(2000,2001,2002)$ and Foster and Archbold (2001). The Cimmeriella fauna recognized in the Mojón de Hierro Formation in southern Patagonia, among others common brachiopod genera with eastern Gondwana such Neilotreta, Arctictreta, Quinquenella, Spirelhyta and Neochonetes (Taboada and Pagani, 2010; Pagani and Taboada, 2011) reinforced the transgondwanan marine connection throughout the proto $\mathrm{V}$-shaped rift system transient (Asseliann-Sakmarian) marine corridor, connecting the eastern Khisr Sagar and western Terra Australis seas (Taboada et al., 2013). The Khsir Sagar sea end (Kapoor and Maheshwari, 1991) or would became in the Meso-Tethys ocean (Metcalfe, 1995, 2009), after rifting and northward drifting of the Cimmerian Continent and associated Terranes, now stretching from the Middle East to Southeast Asia, before have consumed the Paleotethys ocean (Sengör, 1979).

The Indolarian/Austrazean faunal province was recognized in eastern Australia (Shi and Archbold, 1993; Shen et al., 2013; Cisterna and Shi, 2014) where a number of brachiopods (Nambuccalinus, Tomiopsis, Biconvexiella, Quinquenella, Trigonotreta) and bivalves genera (Eurydesma, Deltopecten) possibly migrated or evolved from western Australia-India-Cimmerian Continent, including the faunal imput from western Gondwana trough the W-E trans-gondwanan connection (see also Waterhouse, 2011). Conversely, a reverse migration pattern from eastern to western Gondwana appeared to be documented by the Cimmeriella fauna in southern Patagonia.

\section{Conclusions}

The biocorrelation of the marine invertebrate fauna recorded in the post-glacial succession of the uppermost portion of the Late Paleozoic Itararé Group (Taciba Formation), Paraná Basin, Brazil, is firmly constrained with other well-dated Gondwanan assemblages, and a latest Asselian-early Sakmarian age is suggested. Seven species were identified and illustrated: Lyonia rochacamposi sp. nov. (Butiá assemblage), Langella imbituvensis (Oliveira),? Streptorhynchus sp.,? Cyrtella sp., Tomiopsis sp. cf. T. harringtoni Archbold and Thomas, Quinquenella rionegrensis (Oliveira) and Biconvexiella roxoi Oliveira (Teixeira Soares assemblages).

The presence of Tomiopsis sp. cf. T. harringtoni and the bivalve Atomodesma (Aphanaia) orbirugata in the Teixeira Soares beds and the associated bivalves Myonia argentinensis and Heteropecten paranaensis, both recorded in deposits at Teixeira Soares and Mafra (Butiá), suggest a biocorrelation with the Eurydesma fauna from the Bonete Formation, Sauce Grande-Colorado Basin, Argentina. The Myonia argentinensisAtomodesma (Aphanaia) orbirugata-Heteropectenparanaensis association (MAH) assemblage is proposed here to recognize a regional stratigraphic interval, or Subzone, within the Biozone of Eurydesma. The MAH interbasinal assemblage is recorded in the Sauce Grande and Paraná basins, including faunas of the Capivari Formation, northernmost Paraná Basin.

The faunal assemblages of the Lontras and its correlatives, coupled with radiometric ages from the Ganigobis shale Member, constrain the younger Eurydesma fauna to post-Gzhelian times.

A V-shaped proto-rift system through two major axes of extensional basin development, formed by a north-northwesterly trending axis paralleling the future South Atlantic and a broadly north-northeasterly trending line of separation related to the future Indian Ocean, coupled with a sea-level rise of at least $100 \mathrm{~m}$, favored the establishment of a long narrow shallow seaway allowing faunal exchange between eastern and western Gondwana.

A general W-E Gondwanan Eurydesma-Lyonia faunal migration pattern trend is suggested during Asselian-early Sakmarian times but reversed in the late Sakmarian with the incoming of the Cimmeriella fauna in southern Patagonia.

\section{Acknowledgments}

We thank Dr. Alexander Biakov and an anonymous reviewer, as well as the editor Prof. David J. Bottjer, for their usefull comments on the manuscript. We are grateful to FAPESP for financial support (Grant 2014/09149-0) which enabled ACT to stay in Brazil during the spring of 2014, studying the brachiopod collections of various institutions. We are deeply indebted to Vilson Greinert (CENPALEO) for his assistance during the field trips in Mafra, state of Santa Catarina. We also thank Ivone Cardoso Gonzales (IGc/USP) for her support and collaboration during the examination of the scientific collection of IGc/USP. This is a contribution to the FAPESP (1993/02747-0; 2009/17555-0, 2013/ 25317-7, 2014/09149-0) projects. Grants PIP 237-CONICET, PICTs 1589 and 0584 by FONCYT provided financial support, and the Centro de Investigaciones Esquel de Montaña y Estepa Patagónicas (CIEMEP) supplied laboratory facilities for ACT.

\section{Appendix A. Systematic paleontology}

Phyllum Brachiopoda Duméril, 1806

Order Productida Sarytcheva and Sokolskaya, 1959

Suborder Linoproductidina Waterhouse, 2013

Superfamily Proboscidelloidea Muir-Wood \& Cooper, 1960

Family Auriculispinidae Waterhouse, 1986

Subfamily Lyoniinae Waterhouse, 2001

Tribe Lyoniini Waterhouse, 2001

Genus Lyonia Archbold, 1983b 
Type species: Linoproductus (Cancrinella) cancriniformis var. lyoni Prendergast, 1943, from Lyons Group (Lower Permian), Carnarvon Basin, Western Australia.

Discussion: Closer genera to Lyonia are Nambuccalinus Waterhouse, 2001 and Bandoproductus Jin and Sun, 1981. When compared to Nambuccalinus (type species Lyonia bourkei Briggs, 1998) Lyonia has only one row of cardinal spines, far fewer dorsal spines, and numerous pits over the dorsal exterior (Briggs, 1998; Waterhouse, 2001). Lyonia differs from Bandoproductus by the presence of dorsal spines, lower cardinal process and longer median septum (Archbold, 1983b).

Lyonia rochacamposi sp. nov.

Plate II, Figs. A-O

1969 Cancrinella sp. Rocha Campos, p. 105, pl. X, figs. 1-5, 8. 1969 Linoproductus sp. Rocha Campos, p. 106, pl. X, figs. 6-7.

Material: One hundred seven specimens among internal and external moulds of ventral and dorsal valves. Holotype: CP.I 769 I. Paratypes: CP.I 763, 5011, DZP 18913, 19133B. Other material: CP.I 750-757, 759760, 762, 764-767, 769 II, 781, 2153-2158, 2162; CP.E 536, $3682-$ 3697, 4392-4396 A and B, 5003-5009, 5014-5015; DZP 18821, 18,885-18,896, 18,898-18903a and b, 18,904-18,907, 18,909-18,917, 18,969-18,977, 18,981-18,983; 18,913, 19,133 A.

Locality, unit and age: Fossil site 3, Pedreira (Quarry) Butiá, Bela Vista do Sul district, Mafra County, state of Santa Catarina State, Brazil. Butiá siltstone, uppermost portion of the Taciba Formation, Paraná Basin. Latest Asselian-earliest Sakmarian.

Etymology: In honor of its discoverer and outstanding Brazilian paleontologist and geologist Antonio Carlos Rocha-Campos, Institute of Geosciences, University of São Paulo.

Diagnosis: Average-sized Lyonia, subelliptical transverse outline and gently concave-moderate convex profile. Maximum ventral valve width equal or close to hinge line, with maximum dimensions up to $50 \mathrm{~mm}$ width, $40 \mathrm{~mm}$ length, and width/length ratio between 1.13/ 1.25. Ornamentation of fine radial costellae $(8-12 / 5 \mathrm{~mm}$ on the venter) and ventral spine bases in roughly quincuncial to uneven arrangement. Dorsal valve flat to gently concave with strong genicule. Geniculation beginning at $50^{\circ}$ angle and reaching up $100^{\circ}$ toward end of short trail. Thin median septum half of valve length

Description: Average-sized Lyonia, subelliptical transverse outline and gently concave-moderate convex profile. Maximum ventral valve width equal or close to hinge line, with maximum dimensions up to $50 \mathrm{~mm}$ wide, $32 \mathrm{~mm}$ long, and width/length ratio between 1.30/1.56. Ventral valve moderate convex to subglobose, with largeflatten ears (rarely preserved), cardinal ends at right angles and not distinct trail. Ornamentation of fine radial costellae (the number of costellae per milimeter varies between 8 and 12 but most specimens have 9-10 costellae per $5 \mathrm{~mm}$ on the venter), weak rugae on venter slightly stronger on ears. Costellae number increasing by splitting into two ribs anteriorly from a slightly swollen minute spine bases in roughly quincuncial to uneven arrangement. A single row of spines, coarser than those on the venter on hinge line, occasionally with one or two extra hinge spines (not a second row), although this character is not well preserved. Internal ornament reflects external ornament being other internal characters imperceptibles.

Dorsal valve flat to gently concave with strong genicule. Geniculation beginning at $50^{\circ}$ angle and reaching up $100^{\circ}$ toward end ofshort trail. Rugae and costellae similar to ventral valve, slightly elongate small dimples variably arranged and minute erect spines scattered anteriorly half of dorsal valve length, more densely grouped toward genicule.Thin median septum half of valve length. Cardinal process small and bilobed, subelliptical outline (not well preserved) apparently without continuity with the median septum. Internal ornament reflects external ornament.

Discussion: The studied specimens exhibit moderately large size, gently concave-convex profile, transverse outline, large flattened ears, single row of hinge spines, distinct costellae, ventral and dorsal spines, and thin long dorsal median septum, allowing its assignment to Lyonia Archbold, 1983b. The type species Lyonia lyoni (Prendergast, 1943) from the Lyons Group (Early Permian), Carnarvon Basin, Western Australia (Archbold, 1983b; Skwarko, 1993; Waterhouse, 2011) resembles Lyonia rochacamposi sp. nov. in morphology, ornamentation and internal characters. Nevertheless, the Brazilian species is more transverse, has finer costellae and exhibit stronger geniculation at higher angle. Other overseas species assigned to Lyonia such as L. lyoni by Lapparent et al. (1971), early Permian of Afghanistan, and $L$. sp. by Angiolini (1995), early Permian of Pakistan, lack both dorsal valves preventing detailed comparisons. Lyonia rochamposi sp. nov. was originally described (but not published) as Cancrinella sp. by Rocha Campos (1969), a tentative assignation based on limited (6) topotypic ventral valves. Rocha Campos' specimens share all ventral valve diagnostic features of Lyonia rochacamposi sp. nov. Likewise, Linoproductus sp. of Rocha Campos (1969) grouped two compressed less spinous specimens from the same type locality (fossil site 3, Butiá quarry) which are interpreted representing intraspecific variations and included here in Lyonia rochacamposi sp. nov.

\section{Order Orthotetida Waagen, 1884}

Suborder Orthotetidina Waagen, 1884

Superfamily Orthotetoidea Waagen, 1884

Family Schichertellidae Williams, 1953

Subfamily Steptorhynchinae Stehli, 1954

Genus Streptorhynchus King, 1850

Type species: Terebratulites pelargonatus Schlotheim, 1816, from the Middle Permian of Gera, Germany.

\section{?Streptorhynchus sp.}

Plate III, Fig. A

Locality, unit and age: Fossil site 2, Texeira Soares County, state of Paraná, Brazil. Baitaca siltstone, uppermost portion of the Taciba Formation. Latest Asselian-earliest Sakmarian.

Comments: One illustrated exterior of dorsal valve (DGM 4355) suggests the presence of Streptorhynchus or and allied genus in the Taciba Formation. It is gently convex of subquadrate outline, $17 \mathrm{~mm}$ width and $14.5 \mathrm{~mm}$ length, with its maximum width at $2 / 3$ of valve length. Ornamentation of fine costellae $(3 / \mathrm{mm}$ at the anterior margin), fine growth lines $(6-7 / \mathrm{mm})$ and few marked constrictions anteriorly. Rocha Campos (1969) indicated this same specimen evenly to Streptorhynchus or Kiangsella Grabau (in Chao, 1927). Kiangsiella exhibits stronger costellae or two order sizes although more marked in younger representatives of the genus (Angiolini et al., 2005). Scarcity and deficient preservation of available material do not allow an accurate generic identification. Previously, Streptorhynchus sp. was indicated (not described or published) by Beurlen (in Lange, 1954) for these same unit (formerly Teixeira Soares Formation in Lange, 1954).

Order Spiriferinida Cooper and Grant, 1976

Suborder Spiriferinidina Ivanova, 1972

Superfamily Syringothyridoidea Fredericks, 1926

Family Syringothyrididae Fredericks, 1926

Subfamily Permasyrinxinae Waterhouse, 1986

Genus Cyrtella Fredericks, 1924

Type species: Cyrtia kulikiana Fredericks, 1916, from Cisuralian of northern Russia, by original designation.

?Cyrtella sp.

Plate III, Figs. N-P

Material: Two internal molds of dorsal valves, one of them with its counterpart, one internal mold of a broken posteriorly ventral valve. DZP 18829B, DZP 19134.

Locality, unit and age: Fossil site 2, Texeira Soares County, state of Paraná, Brazil. Baitaca siltstone, uppermost portion of the Taciba Formation. Latest Asselian-earliest Sakmarian. 
Comments: The material exhibits spiriferiform outline with estimated $34 \mathrm{~mm}$ width and $24 \mathrm{~mm}$ length with $1.41 \mathrm{~W} / \mathrm{L}$ ratio, smooth sulcus, furrowed fold on posterior half -length and 10 simple rounded plica on each flank. It recalls Cyrtella Fredericks, 1927 or an allied genus, although without available interareas, interior features and microornamentation, generic assignation remains dubious.

Order Spiriferida Waagen, 1883

Suborder Spiriferidina Waagen, 1883

Superfamily Martinoidea Waagen, 1883

Family Ingelarellidae Campbell, 1959

Subfamily Ingelarellinae Campbell, 1959

Genus Tomiopsis Benediktova, 1956

Type species: Brachthyris kumpani Yanishevskiy, 1935 from the Early Carboniferous of Kuznetsk Basin, Russia.

Tomiopsis sp. cf. T. harringtoni Archbold and Thomas, 1986

Plate III, Figs. B-C

Material: A single distorted mold of ventral valve interior, GP/1E 4364. Locality, unit and age: Fossil site 2, Texeira Soares County, state of Paraná, Brazil. Baitaca siltstone, uppermost portion of the Taciba Formation. Latest Asselian-earliest Sakmarian.

Description: Small-sized Tomiopsis of rounded transverse outline, $15 \mathrm{~mm}$ width and $10 \mathrm{~mm}$ length (estimated), gently lamellose anteriorly. Umbo distinct, hinge length shorter than maximum width, which is located at two-thirds of valve length. Sulcus rounded, lateral slopes with 4 low rounded plicae less stronger posteriorly. Adminicula slightly divergent $\left(\approx 15^{\circ}\right)$ and gently curved enclosing a wide subelliptical muscle field with a thin shallow myophragm-like median septum anteriorly. Muscle scars indistinct.

Discussion: The specimen shares size, shape, number and nature of plicae with the closest species Tomiopsis harringtoni Archbold and Thomas, 1986 (= Notospirifer darwini (Morris) Harrington, 1955) (see also Amos, 1979) from the Bonete Formation (early Permian), Sauce Grande-Colorado Basin, Argentina. The Brazilian specimen exhibits adminicula slightly less diverging and a thin myophragm-like median septum when compared to T. harringtoni. These subtle differences and scarcity of material prevent its assignation to T. harringtoni. Other comparable species is Tomiopsis notoplicatus Archbold and Thomas, 1986 (see also Skwarko, 1993), from the Lyons Group and Carrandiby Formation (early Permian), particularly to the specimen CPC 24242 (from the lowest fossil-bearing horizon of Lyons Group), Carnarvon Basin, Western Australia. This oldest specimen of T. notoplicatus has weaker plicae such as those present in Tomiopsis sp. cf. T. harringtoni, although the former is distinguished by its straight and shorter adminicula. Tomiopsis sp. cf. T. harringtoni (Harrington) was previously assigned (unpublished) to Notospirifer sp. by Rocha Campos (1969) and compared with Argentine specimens assigned to Notospirifer darwini (Morris) by Harrington (1955), currently Tomiopsis harringtoni Archbold and Thomas, 1986.

Superfamily Ambocoeloioidea George, 1931

Family Ambocoeliidae George, 1931

Subfamily Ambocoeliinae George, 1931

Genus Biconvexiella Waterhouse, 1983

Type species: Attenuatella convexa Armstrong, 1968, from the Tiverton Formation (early Permian), Bowen Basin, Queensland, Australia.

Biconvexiella roxoi (Oliveira, 1936)

Plate IV, Figs. A-G

1936 Ambocoelia roxoi Oliveira, p. 9-10, figs. 1-3

1952 Crurithyris roxoi (Oliveira, 1936), Lange, p. 86-88, pl. 1, figs. 4-5 1969 Attenuatella roxoi (Oliveira, 1936), Rocha Campos, p. 113--114, pl. XI, figs. 16, 18

Material: Available topotypic material are one ventral valve internal mold labeled GP/1E 4367 (=DGP 3666 in Rocha Campos, 1969).
Other material are two butterflied ventral and dorsal internal molds, GP/1E 4373 or RG9A (=URS 9 A in Rocha Campos, 1969) and GP/ $1 \mathrm{E} 4437$ (= P235 and "hypotype" of Lange, 1952). Others three ventral valve internal molds (not revised) are DGM E 378 (in Rocha Campos, 1969), DGM 3232 and 3233 (in Oliveira, 1936), this last one dessignated as holotype by Lange (1952).

Locality, unit and age: Fossil site 2 (Baitaca stream margins), Texeira Soares County, state of Paraná, Brazil. Baitaca siltstone (GP/1E 4373 or RG9A) and Passinho shale (GP/1E 4367, DGM E 378, DGM 32323233). Fossil site 1, Restinga (Imbituva), Texeira Soares County, state of Paraná, Brazil. Passinho shale (GP/1E 4437). Uppermost portion of the Taciba Formation. Latest Asselian-earliest Sakmarian.

Description: Average-sized Biconvexiella of plane-strong convex profile, subcircular anterior outline and broad convex posteriorly, subequal in width and length. Maximum width up $9 \mathrm{~mm}$, maximum length up $11 \mathrm{~mm}$ with an W/L ratio varying between $0.73-0.82$ and $\mathrm{W} / \mathrm{L}$ average of 0.78 , with slightly transverse dorsal valve (W/L average of 1.2$)$ and hinge line shorter than maximum width which is located nearly valve midlenght. Ventral valve strongly convex with its stronger convexity in the umbonal region. Median sinus very shallow and narrow. Umbo rounded slightly incurved over hinge line not concealing the delthyrium. Umbonal angle of $75^{\circ}$. Interior of ventral valve with, in nearly $1 \mathrm{~mm}$ width, a well developed long (2/3 ventral valve length), narrow median adductor ridge bounded by two narrow elongate depressed diductor scars. Dorsal valve flat to slightly concave of subcircular to subelipticall transverse outline. Crural plates short, straight to slightly divergent. Small subrectangular $(0.8 \mathrm{~mm}$ width, $2 \mathrm{~mm}$ length) posterior adductor scars separated by a short $(2.5 \mathrm{~mm}$ lenght) thin median ridge. Anterior diductor scars not discernible. Cardinal process tuberculate.

Discussion: The material described here was originally referred to Ambocoelia Hall, 1860 (Oliveira, 1936), later to Crurithyris George, 1931 (Lange, 1952) and Attenuatella Stehli, 1954 (Rocha Campos, 1969, 1970), all of them with similar external spinose microornamentation. Ambocoelia is characterized by a hinge-line equal to its greatest width, a moderate to strong incurved umbo, a bifid cardinal process, and a dorsal musculature consisting of four equal-sized quadrate adductors (Hall, 1860; He et al., 2007; Zambito and Schemm-Gregory, 2013). The Brazilian specimens possess a slightly incurved umbo, the hinge-line shorter than maximum width and a minute tuberculate cardinal process, unlike Ambocoelia. Crurithyris is characterized by a subrounded to transversely ovate shell outline, a hinge-line shorter than maximum width, a moderately to strong incurved ventral umbo, a pair of centrally depressed ventral adductor scars bisected by a thin ridge or absent, a pair of laterally depressed diductor scars, which are separated from their adjacent adductor scars by ridges, and a pair of dorsal adductors scars bisected by a median ridge (George, 1931; Stehli, 1954; He et al., 2007, 2012). The Brazilian specimens although very close to Crurithyris have a more longitudinally elongate outline, a less incurved ventral umbo and a well-developed ventral median ridge. Attenuatella Stehli, 1954 is distinguished from the Brazilian specimens by its unique attenuated outline, a stronger convex ventral valve and umbo strongly incurved (up $180^{\circ}$ ) concealing the apical part of the delthyrium, as well as different arrangement and proportions of muscle scars (Stehli, 1954; Waterhouse, 1964; Landis and Waterhouse, 1966; Shi and Waterhouse, 1996; He et al., 2007, 2012). Attenuatella convexa Armstrong, 1968, type species of Biconvenxiella Waterhouse, 1983, shares with the Brazilian ambocoelids, shell shape, slightly incurved umbo, strong ventral median ridge supporting muscle scars and a dorsal thin median ridge separating adductors scars, that collectively allow consider to be both forms congeneric. Biconvexiella convexa (Armstrong) from the Tiverton Formation (Sakmarian), Bowen Basin, Queensland, Australia, also present in the Farley Formation, Sydney Basin, New South Wales, Australia (Armstrong and Telford, 1970), possess a gently convex dorsal valve and two pairs of adductors scars, being the posterior pair scars smaller than anterior pair scars (Shi and Waterhouse, 1996; He et al., 2007). These last both features 
although lacking in the Brazilian specimens, which exhibit a flat dorsal valve and the anterior pair of adductor scars are not discernible, do not prevent its assignation to Biconvexiella Waterhouse, 1983. Furthermore, a flat dorsal valve was indicated to Biconvexiella aff. B. elgae (Besnossova in Besnossova et al., 1968) from the Kokpekten Complex (GhzelianAsselian) of Kazakhstan by Shi and Waterhouse (1996). Biconvexiella spp. (formerly Crurithyris roxoi/Crurithyris aff. C. planoconvexa Shumard/ Attenuatella sp. in Mendes, 1952; Rocha Campos, 1970; Rocha Campos and Rösler, 1978; Mezzalira, 1989, and others) occur profusely in units close stratigraphically to the Taciba Formation, such as Mafra Formation and Lontras shales and the Capivari Formation, showing the two pairs of adductors scars being the posterior pair scars smaller than anterior pair scars (Plate IV, figures $\mathrm{H}-\mathrm{J}$ ).

Amos (1958; see also Amos, 1979) attributed specimens from the upper part of the "Tepuel System" (more precisely base of LS9 member of Las Salinas Formation of González, 1972; roughly Kasimovian in age), Tepuel-Geona Basin, Chubut Province, Argentina, to Crurithyris roxoi (Oliveira). This assignation was questioned by Rocha Campos (1969) who indicated the absence of a well-developed ventral median ridge in the Patagonian specimens, unlike its presence in Biconvenxiella roxoi (Oliveira). Patagonian topotypic material collected (Plate IV, Figs. KM) $2 \mathrm{~km} \mathrm{SSW}$ of the Nazer store (="boliche and estafeta Las Salinas" in Amos, 1958) by the first author, show a ventral interior with a wide subelliptical depressed muscle field, narrow elongate aductor scars bisected by a thin median ridge and subelliptical diductors separated from the adductor scars by thin short ridges. Dorsal valve gently concave with strong median ridge separating a single pair of relatively large subrectangular adductor scars. Externally they exhibit a gently concave-moderately convex profile with a narrow shallow sinus, a slightly transverse outline, hinge line shorter than maximum width, the umbo moderately incurved, gently lamellose with spinose microornamentation of one order in concentric arrangement. When compared to Biconvexiella roxoi (Oliveira) the Patagonian specimens have up twice the size of the Brazilian species and a different profile, more transverse outline, distinct ventral and dorsal muscle scars, thinner ventral median ridge and stronger dorsal median ridge. The assignment of the Amos' Patagonian species to Crurithyris George, 1931 is confirmed here but not its previous co-specific condition with $B$. roxoi (Oliveira).

Order Chonetida Nalivkin, 1979

Suborder Chonetidina Muir-Wood, 1955

Superfamily Chonetoidea Bronn, 1862

Family Rugosochonetidae Muir-Wood, 1962

Subfamily Quinquenellinae Archbold, 1981

Genus Quinquenella Waterhouse, 1975

Type species: Quinquenella glabra Waterhouse, 1975 from the Nambdo Member of the Senja Formation (Late Permian), east Jumla City, northwest Nepal, by original designation.

Quinquenella rionegrensis (Oliveira, 1930)

Plate III, Figs. D-L

1930 Chonetes rionegrensis Oliveira, p. 19, unnumbered figure

Material: Four dorsal valves (exteriors and interiors), one fragmentary ventral valve interior and one external mold of ventral valve. Lectotype by present designation, GP/1E 4439b; Paralectotypes by present designation, GP/1E 4439a, 2056, 4402; Other material, DZP 19139 and a missing sample of the IGc/USP (Plate III, figure I).

Locality, unit and age: Fossil site 2, Texeira Soares County, state of Paraná, Brazil. Baitaca siltstone (DZP 19139) and Passinho shale (GP/1E 2056; 4439a, b; 4402), uppermost portion of the Taciba Formation. Latest Asselian-earliest Sakmarian.

Diagnosis: Average-sized Quinquenella of subelliptical transverse outline of gentle concave-convex profile and maximum width at hinge line. Maximum width up $10 \mathrm{~mm}$, maximum length up $7 \mathrm{~mm}$ with an
$\mathrm{W} / \mathrm{L}$ ratio varying between $1.43-1.60$ and $\mathrm{W} / \mathrm{L}$ average of 1.53 . Ventral valve moderately concave, smooth with umbonal angle nearly $150^{\circ}$, ortomorph oblique hinge spines and short ventral median septum. Dorsal valve smooth, gentle concave on visceral disk, flattened towards auricles and flanks, auricles poorly differentiated with its margins at right angles. Dorsal interior with short lateral septa (?), thin long accessory septa, ill-defined median septum, fused posteriorly into low platform surrounding a small, circular shallow alveolus.

Description: Average-sized Quinquenella of subelliptical transverse outline of gentle concave-convex profile and maximum width at hinge line. Maximum width up $10 \mathrm{~mm}$, maximum length up $7 \mathrm{~mm}$ with an W/L ratio varying between $1.43-1.60$ and $\mathrm{W} / \mathrm{L}$ average of 1.53 . Ventral valve moderately concave, smooth with umbonal angle nearly $150^{\circ}$, ortomorph oblique hinge spines (few preserved) and internally with a short $(\approx 1 \mathrm{~mm})$ median septum. Dorsal valve smooth, gentle concave on visceral disk, flattened towards auricles and flanks, auricles poorly differentiated with its margins at right angles and apparently gentle concave longitudinally striated interarea. Dorsal interior with short lateral septa (?), thin long accessory septa, ill-defined median septum, fused posteriorly into low platform surrounding a small, circular shallow alveolus. Lines of pustules radially aligned, less densely grouped toward lateral margins. Muscle scars and brachial field inconspicuous. Cardinal process apparently bilobed externally.

Discussion: Oliveira (1930, p. 19) described briefly the Texeira Soares' chonetids having "small size ( $7.5 \mathrm{~mm}$ width/4.25 mm length), semicircular transverse outline, ornamented with radial striae and ventral hinge spines". A single specimen and holotype (supposedly a ventral valve) was illustrated (sketch) in an unnumbered figure (Oliveira, 1930) (Text-Fig. 1). The holotype lacks collection register number, therefore it does not fulfils the 73C.6 recommendation of the ICZN on holotype data.
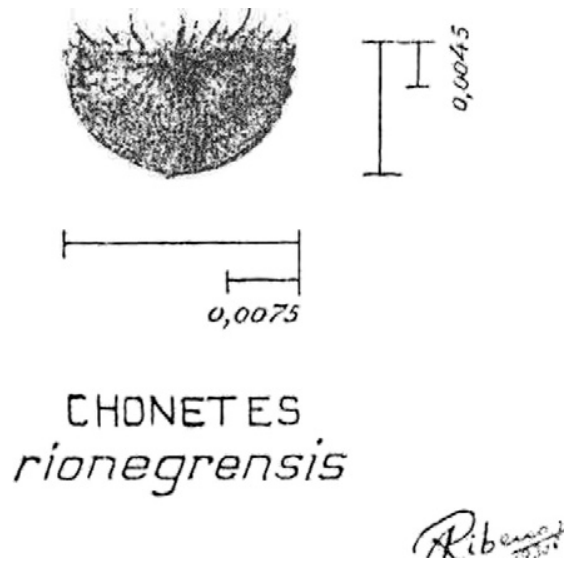

Text-Fig. 1: Original illustration of "Chonetes" rionegrensis Oliveira, 1930.

A collection label of some available specimens (housed in the Seção de Paleontologia da Divisão de Geologia e Mineralogia, Departamento Nacional da Produção Mineral, Rio de Janeiro State, Brazil, numbered GP/1E 4439a, 4439b and 4402), indicates its provenance, collector and date as follow: from the Texeira Soares locality, collected by Dr. Euzébio de Oliveira, in 1908. Consequently, they appear to be the syntype series on which Oliveira (1930) based his study. These and other topotypic specimens are herein figured (Plate III, Figures D-L), although unfortunately none of them matches exactly with the illustrated specimen named Chonetes rionegrensis by Oliveira (1930) (see Text-Fig. 1 ), being this denomination a possible nomen dubium. On the other hand, Rocha Campos (1970) examined the above mentioned syntype series and reassigned Chonetes rionegrenis to the smooth chonetid Lissochonetes Dunbar and Condra, 1932, in agreement to the 
description herein offered. Possibly, the sketch of Chonetes rionegrensis of Oliveira (1930) (Fig. 4) represents an idealized composition of main characters observed by Oliveira, although confusing the external radial ornament with the internal radial dorsal accessory septa, also exaggerating number and dimensions of hinge spines. Furthermore, the supposed ventral valve drew in Oliveira (1930) did not exhibits a moderate convexity, but it matches in shape, size and gentle convexity flattened towards auricles and margins, to the specimen GP/1E $4439 \mathrm{~b}$ (a dorsal valve mould) of the syntype series. This specimen is here selected as lectoype by inference of holotype, supporting rionegrensis as an available and valid name.

Archbold (1983a) based in Oliveira's illustration interpreted Chonetes rionegrensis as an endemic genus, possessing an external radial ornament and numerous and large ventral hinge spines, unlike any other known chonetacean. According to the description herein provided, the chonetids from Texeira Soares show smooth exterior, low concave-moderate convex profile, tranverse outline, ventral median septum, oblique hinge spines and long thin accessory septa that collectively suggest its inclusion in Quinquenella Waterhouse, 1975, more than in Lissochonetes Dunbar and Condra, 1932 as suggested by Rocha Campos (1970) or such as Archbold (1983a) indicated in a new endemic genus. Lissochonetes exhibits well developed dorsal median septum and lacks accessory septa unlike Quinquenella.

Quinquenella rionegrensis (Oliveira) is close to the type species Quinquenella glabra Waterhouse, 1975 (see also Waterhouse, 1978) from the Nambdo Member of the Senja Formation (Late Permian), northwest Nepal (also recorded in the Juripu Formation of southern Tibet by Shi et al., 2003), sharing comparable size and outline, but the late can be differentiated from the Brazilian species by its more inflated ventral valve and stronger developed internal characters. Quinquenella australis Archbold, 1981 (see also Skwarko, 1993) from the Cunlego Formation (late Artinskian) of the Carnarvon Basin, Western Australia, is larger, has subquadrate less transverse outline, longer ventral median septum and stronger internal characters of dorsal valve when compared to Q.rionegrensis (Oliveira). Quinquenella kuwanensis (Waterhouse, 1978) (Shen et al., 2001) from the Kuwa Member of the Senja Formation (late Permian) of northwest Nepal, exhibits similar transverse outline with $Q$. rionegrensis (Oliveira), although the former has smaller average-size, almost flat dorsal valve, longer ventral valve median septum and well impressed dorsal muscle scars. Quinquenella planoconvexa Abramov and Grigorjewa, 1988, as well as Quinquenella pseudobrama (Zavodowsky, 1960) (Abramov, 1970; Abramov and Grigorjewa, 1988; Klets, 2005a,b), from the Khorokytian and Echian Horizons (Asselian-Artinskian) of Verchojan region, northeast Asia, have subquadrate to subcircular outlines, inflated ventral valves, dorsal valves flat, long ventral median septum and strong accessory septa, unlike Q. rionegrensis (Oliveira). Quinquenella? sp. Archbold, 1999, from the Phuket/Kaeng Krachan Group (late Asselian-Sakmarian), Thailand, is a small species with unknown dorsal valve, preventing accurate comparison. Quinquenella sp. by Taboada and Shi (2009) (formerly Tornquistia sp. of Amos, 1960; Yagonia sp. of Roberts in Roberts et al., 1976, Amos, 1979; Archangelsky, 1987; Cúneo and Sabattini, 1987; Lissochonetes jachalensis of Simanauskas, 1991, in part) from the Mojón de Hierro (late Sakmarian) and Río Genoa (early Artinskian) formations, Tepuel-Genoa Basin, Patagonia Argentina, exhibits hinge margin shorter than maximum width, subcircular outline, longer ventral septum and shorter accessory septa that distinguish it from Q. rionegrensis (Oliveira).

Subphylum Linguliformea Williams, Carlson, Brunton, Holmer and Popov, 1996

Class Lingulata Gorjansky and Popov, 1985

Order Lingulida Waagen, 1885

Superfamily Linguloidea Menke, 1828

Family Lingulidae Menke, 1828

Genus Langella Mendes, 1961
Type species: Lingula imbituvensis de Oliveira, 1930 from the Passinho drill core (120 m depth), Passinho Creek, $15 \mathrm{~km}$ from Texeira Soares City, Paraná State, Brazil. Passinho Shale, uppermost Taciba Formation, late Pennsylvanian-early Sakmarian.

Langella imbituvensis (Oliveira, 1930)

Plate III, Fig. M

1930 Lingula imbituvensis Oliveira, p. 18-22, fig. 1

1948 Lingula budoensis Martins, p. 237, figs. 1-2

1949 Lingula sp. Pinto, p. 3, figs. 2a-2b

1952 Barroisella imbituvensis (Oliveira) Lange, p. 83-86, Pl. 4, figs.1-8. 1961 Langella imbituvensis (Oliveira) Mendes, 3-5, Pl. 1, Figs. 1-2, Pl. 2 , Figs. 1-3, Text-Fig. 1-3.

Locality, unit and age: Fossil site 2, Texeira Soares County, state of Paraná, Brazil. Passinho shale, uppermost portion of the Taciba Formation. Latest Asselian-earliest Sakmarian.

Comments: One figured dorsal valve external mold (GP/IE 4439) of longitudinally oval outline, ornamented with feebly concentric growth lines, $5.0 \mathrm{~mm}$ in length, $3.0 \mathrm{~mm}$ in width and L/W ratio of 1.67 , suggests Langella imbituvensis (Oliveira, 1930). Holotype (dorsal valve DGM 386) exhibits $6.5 \mathrm{~mm}$ in width, $4.25 \mathrm{~mm}$ in width and a $\mathrm{L} / \mathrm{W}$ ratio of 1.53 , while Lange (1952) reports maximum size of dorsal valves of $6.53 \mathrm{~mm}$ in length, $3.82 \mathrm{~mm}$ in width, with $\mathrm{L} / \mathrm{W}$ ratio of 1.71 . Despite having in hand only one specimen, dimensions are shared with previous description of Oliveira species from the same stratigraphic interval. Furthermore, no other lingulid is known from the Itarare succession where this brachiopod occurs profusely in numbers like no other one.

Langella sp. Sun and Baliński, 2008 (= Lingula sp. of Baliński, 1999) from the Muhua Formation (Tournaisian) of the Gizhou Province, south China, is comparable in size and outline with L. imbituvensis, but its fragmentary record prevent accurate comparison.

\section{References}

Abramov, B.S., 1970. Biostratigrafiya kamennougol'nykh otlozhenii Sette-Dabana (Yuzhnoe Verkhoyan'e). Biostratigraphy of the Carboniferous deposits of SetteDaban Southern Verkhoyan. Nauka, Moscow (178 pp.).

Abramov, B.S., Grigorjewa, A.D., 1988. Biostratigrafiya i brakhiopody permi Verkhoyan'ya. Biostratigraphy And Brachiopods From The Permian Of Verkhoyan. Nauka, Moscow (204 pp.).

Alessandretti, L., Chemale Jr., F., Ramos, V.A., Philipp, R.P., 2010. Idade de deposição dos tufos da Formação Tunas, Sierra de la Ventana foldbelt, Argentina. VI Congreso Uruguayo de Geología, Acta de Resúmenes, Lavalleja (6 pp.).

Almeida, F.F.M., 1945. Episódio da última glaciação permo-carbonífera no Paraná. Divisão de Geologia e Mineralogia, Notas Preliminares e Estudos 27, pp. 1-18.

Amos, A.J., 1958. Algunos Spiriferacea y Terebratulacea (Brach.) del Carbonífero Superior del "Sistema del Tepuel" (Provincia de Chubut). Contribuciones Científicas, Facultad de Ciencias Exactas y Naturales, Universidad de Buenos Aires, Serie Geología 2, pp. 95-108.

Amos, A.J., 1960. Algunos Chonetacea y Productacea del Carbonífero Inferior y Superior del Sistema de Tepuel, Provincia de Chubut. Rev. Asoc. Geol. Argent. 15, 81-107.

Amos, A.J., 1979. Guía Paleontológica Argentina. Parte 1: Paleozoico. Faunas Carbónicas y Pérmicas. Consejo Nacional de Investigaciones Científicas y Técnicas, Buenos Aires (158 pp.).

Andrade, L., 2010. Processos, fácies e geometría do sistema turbidítco da Formação Taciba/ Membro Rio Segredo, faixa aflorante norte catarinense. Instituto de Geociências e Ciências Exatas, Campus de Rio Claro, Universidade Estadual Paulista (85 pp., (Magister thesis unpublished)).

Angiolini, L., 1995. Permian Brachiopods from Karakorum (Pakistan): part 1. (with appendix - new brachiopod taxa from the Bolorian-Murgabian/Midian of Karakorum). Riv. Ital. Paleontol. Stratigr. 101, 165-214.

Angiolini, L., Brunton, H., Gaetani, M., 2005. Early Permian (Asselian) brachiopods from Karakorum (Pakistan) and their palaeobiogeographical significance. Palaeontology 48, 69-86.

Angiolini, L., Jadoul, F., Leng, M.J., Stephenson, M.H., Rushton, J., Chenery, S., Crippa, G., 2009. How cold were the Early Permian glacial tropics? Testing sea-surface temperature using the oxygen isotope composition of rigorously screened brachiopod shells. J. Geol. Soc. Lond. 166, 933-945.

Angiolini, L., Zanchi, A., Zanchetta, S., Nicora, A., Vezzoli, G., 2013. The Cimmerian geopuzzle: new data from South Pamir. Terra Nova 25, 352-360.

Archangelsky, S. (Ed.), 1987. El Sistema Carbonífero en la República Argentina. Córdoba (Argentina), Academia Nacional de Ciencias (383 pp.).

Archbold, N.W., 1981. Studies on Western Australian Permian Brachiopods. 2. The Family Rugosochonetidae. Proc. Roy. Soc. Victoria 93, 109-128.

Archbold, N.W., 1982. Correlation of the Early Permian faunas of Gondwana: implications for the Gondwanan Carboniferous-Permian boundary. J. Geol. Soc. Aust. 29, 267-276. 
Archbold, N.W., 1983a. Permian Marine Invertebrate Provinces of the Gondwanan Realm. Alcheringa 7, 59-73.

Archbold, N.W., 1983b. Studies on Western Australian Permian Brachiopods. 3. The Family Linoproductidae Stehli 1954. Proc. Roy. Soc. Victoria 95, 237-254.

Archbold, N.W., 1993. A zonation of the Permian Brachiopod faunas of western Australia In: Findlay, R.H., Unrug, R., Banks, M.R., Veevers, J.J. (Eds.), Gondwana Eight- Assembly, Evolution and Dispersal. A.A. Balkema, Rotterdam, pp. 313-321.

Archbold, N.W., 1995. Studies on Western Australian Permian Brachiopods 12.Aditions to the Late Asselian-Tastubian faunas. Proc. Roy. Soc. Victoria 107, 95-112.

Archbold, N.W., 1998. 1998. Marine Biostratigraphy and Correlation of the West Australian Permian Basins. In: Purcell, P.G., Purcell, R.R. (Eds.), The Sedimentary Basins of Western Australia 2: Proceedings of Petroleum Exploration Society of Australia Simposium, Perth, WA, pp. 141-151.

Archbold, N.W., 1999. Permian Gondwanan correlations: the significance of the western Australian marine Permian. J. Afr. Earth Sci. 29, 63-75.

Archbold, N.W., 2000. Palaeobiogeography of the Australasian Permian. Assoc. Australas. Paleontol. Mem. 23, 287-310.

Archbold, N.W., 2001. Pan-Gondwanan, Early Permian (Asselian-Sakmarian-Aktastinian) correlations. Contributions to Geology and Palaeontology of Gondwana in honour of Helmut Wopfner, pp. 29-39.

Archbold, N.W., 2002. Peri-Gondwanan Permian correlations: The Meso-Tethyan Margins. In: Keep, M., Moss, S.J. (Eds.), The Sedimentary Basins of Western Australia 3 : Proceedings of the Petroleoum Exploration Society of Australia Symposium, Perth, WA, pp. 223-240.

Archbold, N.W., Barkham, S.T., 1989. Permian Brachiopoda from near Bisnain Village, West Timor. Alcheringa 13, 125-140.

Archbold, N.W., Bird, P.R., 1989. Permian Brachiopoda from near Kasliu Village, West Timor. Alcheringa 13, 103-123.

Archbold, N.W., Gaetani, M., 1993. Early Permian Brachiopoda and Mollusca from the northwest Himalaya, India. Riv. Ital. Paleontol. Stratigr. 99, 27-56.

Archbold, N.W., Hogeboom, T., 2000. Subsurface brachiopoda from borehole cores through the Early Permian sequence of the Carnarvon Basin, Western Australia: correlations with palynological biostratigraphy. Proc. Roy. Soc. Victoria 112, 93-109.

Archbold, N.W., Thomas, G.A., 1986. Permian Ingelarellidae (Brachiopoda) from Western Australia and Argentina. J. Paleontol. 60, 581-605.

Archbold, N.W., Thomas, G.A., Skwarko, S.K., 1993. Brachiopods. In: Skwarko, S.K. (Ed.) Palaeontology of the Permian of Western Australia. Geological Survey of Western Australia, Bulletin 136, pp. 45-51.

Archbold, N.W., Shah, S.C., Dickins, J.M., 1996. Early Permian Brachiopods faunas from Peninsular India: their Gondwanan relationships. Hist. Biol. 11, 125-135.

Armstrong, J., 1968. The unusual brachial skeleton of Attenuatella convexa sp. nov. Palaeontology 2, 783-792.

Armstrong, J., Telford, P., 1970. Species of Attenuatella Stehli (Brachiopoda) from New South Wales. Proc. Linnean Soc. NSW 94, 113-118.

Baliński, A., 1999. Brachiopods and conodonts from the Early Carboniferous of South China. Acta Palaeontol. Pol. 44, 437-451.

Bangert, B., Stollhofen, H., Lorenz, V., Armstrong, R.L., 1999. The geochronology and significance of ash-fall tuffs in the glaciogenic Carboniferous-Permian Dwyka Group in Namibia and South Africa. J. Afr. Earth Sci. 29, 33-49.

Bates, S.M., Lyons, T.W., 2006. A coupled oxygen isotope and trace metalrecord of glacioeustatic sea level variation and enhanced water column productivity. Geol. Soc. Am. Abstr. Programs 38, 183.

Benediktova, R.N., 1956. Spiriferidy Ostrogskoi svity Kuzbassa (Spiriferids of the Ostrogsk series of the Kuzbass). Voprosy Geologii Kuzbassa, Materialy vtorogo soveshcheniya po stratigrafii uglenosnykh otlozhenni 1 pp. 169-182 (in Russian).

Besnossova, G.A., Grigorjeva, A.D., Pavlova, E.E., Sokolskaya, A.N., 1968. Order Spiriferida In: Sarytcheva, T.G. (Ed.), Brakhiopody Verkhnego Paleozoiia Vostchnogo Kazkhstana (Upper Paleozoic Brachiopods of Eastern Kazakhstan). Akademiia Nauk SSSR, Paleontologischeskii Institut, Trudy 121, pp. 166-202 (in Russian).

Beurlen, K., 1954. As faunas de Lamilibrânquios do Sistema Gondwânico no Paraná. In: Lange, F.W. (Ed.), Paleontologia do ParanáComissão de Comemorações do Centenário do Paraná. Curitiba, Paraná, Brasil, pp. 107-136.

Biswas, S.K., 1999. A review on the evolution of rift basins in India during Gondwana with special reference to western Indian basins and their hydrocarbon prospects. Proc. Indian Natl. Sci. Acad. A 65, 261-284.

Briggs, D.J.C., 1998. Permian Productidina and Strophalosiidina from the Sydney-Bowen Basin and new England Orogen: systematics and biostratigraphic significance. Assoc. Australas. Paleontol. Mem. 19, 1-258.

Bronn, H.G., 1862. Die Klassen und Ordnungen der Weichthiere (Malacozoa) vol. 3(1). C. F. Winter'sche Verlagshandlung, Leipizig \& Heidelberg (518 pp.).

Cagliari, J., Correa Lavina, E.L., Philipp, R.P., Wohnrat Tognoli, F.M., Stipp Basei, M.A Faccini, U.F., 2014. New Sakmarian ages for the Rio Bonito Formation (Paraná Basin, southern Brazil) based on LA-ICP-MS U-Pb radiometric dating of zircons crystals. J. S. Am. Earth Sci. 56, 265-277.

Campbell, K.S.W., 1959. The Martiniopsis-like Spiriferids of the Queensland Permian. Palaeontology 1, 333-350.

Carter, J.L., Johnson, J.G., 2006. Spiriferinida. In: Kaesler, R.L. (Ed.)Treatise on Invertebrate Paleontology Pt. H, Brachiopoda (Revised) vol. 5. The Geological Society of America and The University of Kansas, pp. 1877-1937.

Carter, J.L., Johnson, J.G., Gouvernnec, R., Hou, H-f., 2006. Spiriferida. In: Kaesler, R.L. (Ed.)Treatise on Invertebrate Paleontology Pt. H, Brachiopoda (Revised) vol. 5. The Geological Society of America and The University of Kansas, pp. 1689-1864.

Casshyap, S.M., Tewari, R.C., 1987. Depositional model and tectonic evolution of Gondwana basins. Palaeobotanist 36, 59-66.

Castro, J.C. 1999. Estratigrafia de Sequencias das formações Campo Mourão (Parte Superior) e Taciba, Grupo Itararé, leste da Bacia do Paraná. Rev. Bras. Geol. 29, 225-260.
Cawood, P.A., Nemchin, A.A., 2000. Provenance record of a rift basin: U/Pb ages of detrital zircons from the Perth Basin, Western Australia. Sediment. Geol. 134 (3), 209-234.

Chao, Y.T., 1927. Brachiopod fauna of the Chihsia Limestone. Bull. Geol. Soc. China 6, 83-113.

Cisterna, G.A., Shi, G.R., 2014. Lower Permian brachiopods from Wasp Head Formation, Sydney Basin, southeastern Australia. J. Paleontol. 88, 531-544.

Cohen, K.M., Finney, S.C., Gibbard, P.L., Fan, J.-X., 2013. The ICS International Chronostratigraphic Chart. Episodes 36, 199-204.

Cooper, G.A., Grant, R.E., 1976. Permian brachiopods of West Texas, V. Smithson. Contrib. Paleobiol. 24, 2609-3159.

Crostella, A., 1995. Structural evolution and hydrocarbon potential of the Merlinleigh and Byro Sub-basins, Carnarvon Basin, Western Australia. Western Australia Geological Survey, Report 45 (36 pp.)

Cúneo, R., Sabattini, N., 1987. Flora y Fauna de la base de la Formación Río Genoa en la localidad de Ferrarotti, Pérmico inferior de Chubut, Argentina. $4^{0}$ Congreso Latinoamericano de Paleontologia. Memorias 1, 283-298.

Dana, J.D., 1847. Description of Fossils from Australia. Am. J. Sci. 54, 151-160.

Davydov, V.I., Biakov, A.S., 2015. Discovery of shallow-marine biofacies conodonts in a bioherm within the Carboniferous-Permian transition in the Omolon Massif, NE Russia near the North paleo-pole: Correlation with a warming spike in the southern hemisphere. Gondwana Res. 28, 888-897.

Davydov, V.I., Haig, D.W., McCartain, E., 2013. A latest Carboniferous warming spike recorded by a fusulinid-rich bioherm in Timor Leste: Implications for East Gondwana deglaciation. Palaeogeogr. Palaeoclimatol. Palaeoecol. 376, 22-38.

Dickins, J.M., 1956. Permian Pelecypods from the Carnarvon basin, western Australia. Bur. Mineral Resour. Geol. Geophys. Bull. 29 (42 pp.).

Dickins, J.M., 1957. Permian Pelecypods and gastropods from the Carnarvon basin, western Australia. Bur. Mineral Resour. Geol. Geophys. Bull. 41, 14-75.

Dickins, J.M., 1961. Eurydesma and Peruvispira from the Dwyka Beds of South Africa. Palaeontology 4, 138-148.

Dickins, J.M., 1963. Permian Pelecypods and Gastropods from western Australia. Bur. Mineral Resour. Geol. Geophys. Bull. 63, 1-203.

Dickins, J.M., 1978. Climate of the Permian in Australia: The Invertebrate Faunas. Palaeogeogr. Palaeoclimatol. Palaeoecol. 23, 33-46.

Dickins, J.M., 1985. Late Paleozoic glaciation. Bur. Mineral Resour. J. Aust. Geol. Geophys. 9, 163-169.

Dickins, J.M., 1997. Some problems of the Permian (Asselian) glaciation and the subsequent climate in the Permian. In: Martini, I.P. (Ed.), Late glacial and postglacial environmental changes; Quaternary, Carboniferous-Permian, and Proterozoic. Oxford University Press, New York, NY, United States (USA), pp. 243-245.

Dickins, J.M., 2000. The Northern Margin of Gondwanaland: uppermost Carboniferous to lowermost Jurassic and its correlation. Developments in Palaeontology and Stratigraphy 18 , pp. 257-270.

Dickins, J.M., Shah, S.C., 1981. Permian paleogeography of Peninsular and Himalayan India and the relationship with the Tethyan region. Gondwana Five 79-83. Balkema, Rotterdam.

Dickins, J.M., Shah, S.C., 1987. The relationship of the Indian and western Australian Permian marine faunas. Gondwana Six: Stratigraphy, Sedimentology, and Paleontology 41. American Geophysical Union, pp. 15-20.

Dickins, J.M., Thomas, G.A., 1959. The marine fauna of the Lyons Group and the Carrandibby Formation of the Carnarvon Basin, Western Australia. Bur. Mineral. Resour. Geol. Geophys. Rep. 38, 65-96.

Dickins, J.M., Shah, S.C., Archbold, N.W., Jin, Y.-G., Liang, D.-Y., Liu, B.-P., 1993. Some Climatic and Tectonic Implications of the Permian Marine Faunas of Peninsular India, Himalayas and Tibet. In: Findlay, R.H., Unrug, R., Banks, M.R., Veevers, J.J. (Eds.), Gondwana Eight- Assembly, Evolution and Dispersal. A.A. Balkema, Rotterdam, pp. 333-343.

Duméril, A.M.C., 1806. Zoologie analytique ou method naturelle de classification des animaux. Allais, Paris, p. 334.

Dunbar, C.O., Condra, G.E., 1932. Brachiopoda of the Pennsylvanian system in Nebraska. Nebraska Geological Survey Bulletin (series 2) 5, pp. 1-177.

Elliot, D.H., Fanning, C.M., Laudon, T.S., 2014. The Gondwana Plate margin in the Weddell Sea sector: Zircon geochronology of Upper Paleozoic (mainly Permian) strata from the Ellsworth Mountains and eastern Ellsworth Land, Antarctica. Gondwana Res. http://dx.doi.org/10.1016/j.gr.2014.12.001.

Etheridge Jnr., R., 1907. Official contributions to the palaeontology of South Australia. South Australian Parliament Papers 55 (1906), pp. 1-21 (Supp.).

Feldmann, R.M., Chapman, R.E., Hannibal, J.T., 1989. Paleotechniques. The Paleontologycal Society Special Publications 4 (358 pp.)

Foster, C., Archbold, N., 2001. Chronological anchor points for the Permian and Early Triassic of the Eastern Australian Basins. Contributions to geology and palaeontology of Gondwana in honour of Helmut Wopfner, pp. 175-197.

França, A.B., Potter, P.E., 1988. Estratigrafia, ambiente deposicional e análise de reservatório do Grupo Itararé (Permocarbonífero), Bacia do Paraná (parte 1). Boletim de Geociências da Petrobrás 2, pp. 147-191.

França, A.B., Winter, W.R., Assine, M.L., 1996. Arenitos Lapa-Vila Velha: Um modelo de trato de sistemas subaquosos canal-lobos sob influência glacial, Grupo Itararé (C-P), Bacia do Paraná. Rev. Bras. Geosci. 26, 43-56.

Fredericks, G.N., 1916. Paleontological Notes on Some Upper Paleozoic Brachiopoda of Eurasia. Comite Geologique, Memoires 156, pp. 1-87 (in Russian).

Fredericks, G.N., 1924. Paleontologitcheskie ztoudy.2: O verkhne kamennougolnykh spiriferidakh Ourala (Paleontological studies 2: On the Carboniferous spiriferids from the Urals). Izvestyia geologicheskogo Komiteta 38, pp. 295-324 (in Russian)

Fredericks, G.N., 1926. Tablitsa dlya opredeleniia rodov semeistva Spiriferidae King (Classification table of the genera of the family Spiriferidae King). Akademia Nauk 
SSSR, Izvestiya (Academy of Sciences URSS, Bulletin) (series 6) 20, pp. 393-423 (in Russian).

George, T.N., 1931. Ambocoelia Hall and certain similar British Spiriferidae. Q. J. Geol. Soc. Lond. 87, 30-61.

Ghosh, S.K., 2003. First Record of Marine Bivalves from the Talchir Formation of the Satpura Gondwana Basin, India: Palaeobiogeographic Implications. Gondwana Research (Gondwana Newsletter Section) K 6, pp. 312-320.

González, C.R., 1972. La Formación Las Salinas, Paleozoico superior de Chubut (República Argentina). Parte I. Estratigrafía, facies y ambientes de sedimentación. Rev. Asoc. Geol. Argent. 27, 95-115.

Gorjansky, V.Yu, Popov, L.Ye, 1985. Morfologiia, sistematicheskoe polozhenie i proiskhozhdenie bezzamkovykh brakhiopod s karbonatnoi rakovinoi. (Morphology, Systematic Position and Origin of Inarticulate Brachiopods with a Carbonate Shell). Paleontol. Zh. 3, 3-14 (in Russian).

Gradstein, F.M., Ogg, J.G., Schmitz, M.D., Ogg, G.M., 2012. TheGeological Time Scale 2012. 2 vols. Elsevier, Amsterdam (1144 pp.).

Guerra-Sommer, M., Cazzulo-Klepzig, M., Formoso, M.L.L., Menegat, R., Mendonça, J.G., 2008a. U-Pb dating of tonstein layers from a coal succession of the southern Paraná Basin (Brazil): a new geochronological approach. Gondwana Res. 14, 474-482.

Guerra-Sommer, M., Cazzulo-Klepzig, M., Menegat, Rualdo, Formoso, M.L.L., Basei, M.A.S., Barboza, E.G., Simas, M.W., 2008b. Geochronological data from Faxinalcoal succession in Southern Paraná Basin: a preliminary approach combining radiometric $\mathrm{U} / \mathrm{Pb}$ age and palynostratigraphy. J. S. Am. Earth Sci. 25, 246-256.

Guerra-Sommer, M., Cazzulo-Klepzig, M., Santos, J.O.S., Hartmann, L.A., Ketzer, J.M.M., Formoso, M.L.L., 2008c. Radiometric age determination of tonsteins and stratigraphic constrains for the Lower Permian coal succession in SouthernParaná Basin, Brazil. Int. J. Coal Geol. 74, 13-27.

Haig, D.W., McCartain, E., Mory, A.J., Borges, G., Davydov, V.I., Dixon, M.E., Groflin, A., Hakansson, S., Keep, E., Santos, M., Dos, Z., Shi, G.R., Soares, J., 2014. Postglacial Early Permian (late Sakmarian- early Artinskian) shallow-marine carbonate depositionalong a $2000 \mathrm{~km}$ transect from Timor to west Australia. Palaeogeogr. Palaeoclimatol. Palaeoecol. 409, 180-204.

Hall, J., 1860. Observations of the genus Ambocoelia. Thirteenth Annual Report of the Regents of the University on the condition of the State Cabinet of Natural History, pp. 71-72.

Hamel, M.H., 2005. A new lower actinopterygian from the early Permian of the Parana Basin, Brazil. J. Vertebr. Paleontol. 25, 19-26.

Harrington, H.J., 1955. The Permian Eurydesma fauna of eastern Argentina. J. Paleontol. 29, 112-128.

Harrowfield, M., Holdgate, G.R., Wilson, C.J., McLoughlin, S., 2005. Tectonic significance of the Lambert Graben, East Antarctica: reconstructing the Gondwanan rift. Geology 33, 197-200.

He, W., Shi, G.R., Feng, Q., Peng, Y., 2007. Discovery of late Changhsingian (latest Permian) brachiopod Attenuatella species from South China. Alcheringa 31, 271-284.

He, W., Shi, G.R., Zhang, Y., Yang, T., Teng, F., Wu, S., 2012. Systematics and palaeoecology of Changhsingian (Late Permian) Ambocoeliidae brachiopods from South China and implications for the end-Permian mass extinction. Alcheringa 36, 515-530.

Henderson, Ch.M., Mei, Sh., 2000. Preliminary cool water Permian conodont zonation in north Pangea: A review. Permohiles 36, 16-23.

Hocking, R.M., 1990. Carnarvon Basin, in Geology and mineralresources of Western Australia: Western Australia Geological Survey. Memoir 3, 457-495.

Holz, M., Souza, P.A., Ianuzzi, R., 2008. Sequence stratigraphy and biostratigraphy of the Late Carboniferous to Early Permian glacial succession (Itararé Subgroup) at the eastern-southeastern margin of the Paraná Basin, Brazil. Geol. Soc. Am. Spec. Pap. 441, 115-129.

Holz, M., França, A.B., Souza, P. A, Jannuzzi, R, Rohn, R, 2010. A stratigraphic chart of the Late Carboniferous/Permian succession of the eastern border of the Paraná Basin, Brazil, South America. J. S. Am. Earth Sci. 29, 381-399.

Isbell, J.L., Miller, M.F., Wolfe, K.L., Lenaker, P.A., 2003. Timing of late Paleozoic glaciation in Gondwana: Was glaciation responsible for the development of northern hemisphere cyclothems? In: Chan, M.A., Archer, A.W. (Eds.), Extrem depositional environments: Mega end members in geologic time. Boulder, Colorado, Geological Society of America, Special Paper 370, pp. 5-24

Isbell, J.L., Gulbranson, E.L., Taboada, A.C., Pagani, M.A., Limarino, C.O., Fraiser, M.L., Pauls, K.N., Henry, L.C., 2013. Carboniferous and Permian strata of the Tepuel-Genoa Basin, Patagonia, Argentina: A near-continuous, deep-water record of polar Gondwana during the Late Paleozoic Ice Age. In: Lucas, S.G., et al. (Eds.), The Carboniferous-Permian Transition. New Mexico Museum of Natural History and Science, Bulletin 60, pp. 137-138.

Ivanova, E.A., 1972. Osnovnyye zakonomernosti evolyutsii spiriferid (Brachiopoda) [Main features of spiriferid evolution (Brachiopoda)]. Paleontol. Zh. 3, 28-42 (in Russian).

Jin, Y-g., Sun, D-l., 1981. Paleozoic brachiopods from Xizang. Palaeontology of Xizang, Book III (The Series of the Scientific Expedition to the Qinghai-Xizang Plateau). Science Press, Beijing, pp. 127-176.

Kapoor, H.M., Maheshwari, H.K., 1991. Early Permian palaeogeography of the Perigondwana in the Indian segment. Curr. Sci. 61, 648-653.

Kapoor, H.M., Maheshwari, H.K., Bajpal, U., 1992. "Shir Sagar", Tethys and the Perigondwana-Late Paleozoic evolutionary history of the Gondwana Supercontinent. Symposium on Himalayan Geology Shijane, Shimane, Japan 92, pp. 20-21.

Kegel, W., Costa, M.T., 1952. Nota preliminar sobre a fauna da série Itararé em Rio d’Areia, Estado do Paraná. An. Acad. Bras. Cienc. 34, 171-173.

King, W., 1850. A monograph of the Permian fossils of England. Palaeontographical Society. Monograph 3xxxvii (258 pp.).

Klets, A.G., 2005a. Upper Paleozoic of Marginal Seas of Angarida. Institute of Petroleum Geology of United Institute of Geology, Geophysics and Mineralogy (UIGGM),
Siberian Branch of Russian Academy of Sciences (SB RAS)-Novosibirsk, Academic Publishing House "Geo" (240 pp.).

Klets, A.G., 2005b. Benchmarks for correlation of Carboniferous and Permian marine deposits in Siberia and Far East. Russ. Geol. Geophys. 46 (3), 256-272.

Kling, S.A., Reif, W.W., 1969. The Paleozoic history of amphidisc and hemidisc sponges: new evidence from Carboniferous of Uruguay. J. Paleontol. 43, 1429-1434.

Koninck, L.G. de, 1877. Recherches sur les fossils Paléozoïques de la Nouvelle-Galles du Sud (Australie), Troisième Parties. Fossiles Carboniferères. Mémoires de la Société des Sciences de Liége, Series 2 pp. 29-45.

Kozur, H., 1998. The Permian conodont biochronology.Problemsand Problems. Proc. Roy. Soc. Victoria 110, 197-220.

Landis, C.A., Waterhouse, J.B., 1966. Discovery of Permian fossils in the Eglinton Volcanics, Southland. Transactions of the Royal Society of New Zealand, Geology 4, pp. 139-146. Lange, F.W., 1952. Revisão da fáunula marinha do Folhelho Passinho. Dusenia 3, 81-91.

Lange, F.W., 1954. Paleontologia do Paraná: volume comemorativo do $1^{\circ}$ Centenário do Estado do Paraná. Comissão de Comemorações do Centenário do Paraná (104pp.).

Lapparent, A.F. de, Termier, G., Termier, H., 1971. Découverte de la faune d'Umaria (Permien inférieur de l'Inde) en Afghanistan et conséquences paleogeographiques. C. R. Acad. Sci. 272D, 381-384.

Leonova, T.B., 1999. Permian ammonoids of Russia and Australia. Proc. Roy. Soc. Victoria $110,157-162$.

Leonova, T.B., 2011. Permian ammonoids: biostratigraphic, biogeographical,and ecological analysis. Paleontol. J. 45, 1206-1312.

Lindeque, A., de Wit, M.J., Ryberg, T., Weber, M., Chevallier, L., 2011. Deep crustal profile across the southern Karoo basin and Beattie magnetic anomaly, South Africa: an integrated interpretation with tectonic implications. S. Afr. J. Geol. 114, 265-292.

López Gamundi, O., Fildani, A., Weislogel, A., Rosello, E., 2013. The age of the Tunas Formation in the Sauce Grande basin-Ventana foldbelt (Argentina): Implications for Permian evolution of the southwestern margin of Gondwana. J. S. Am. Earth Sci. 45, 250-258.

Martin, H., Wilczewski, N., 1970. Palaeoecology, conditions of deposition and the palaeogeography of the marine Dwyka beds of S.W.A. In: Haughton, S.H. (Ed.), Proceedings of the Second International Union of Geological Sciences (IUGS) Symposium on Gondwana Stratigraphy and Palaeontology. Council for Scientific and Industrial Research, Pretoria, Pietermaritzburg, South Africa, pp. 621-625.

Martins, E.A., 1948. Fósseis marinhos na série Maricá, Estado do Rio Grande do Sul. Mineração e Metalurgia 12, pp. 237-239.

Matos, S.L.F., Yamamoto, J.K., Riccomini, C., Hachiro, J., Tassinari, C.C.G., 2001. Absolute dating of Permian ash-fall in the Rio Bonito Formation, Paraná Basin, Brazil. Gondwana Res. 4, 421-426.

Mendes, J.C., 1952. Fáunula permo-carbonífera marinha de Capivari. Boletim da Faculdade de Filosofia, Ciências e Letras, Universidade de São Paulo, 134, Geologia 7, pp. 1-18.

Mendes, J.C., 1961. Langella, novo gênero de Lingulídeo da Série Tubarão. Boletim da Universidade do Paraná, Instituto de Geologia 5 pp. 1-8.

Menke, K.T., 1828. Synopsis methodica Molluscorum generum omnium et specierum earum, quae in Museo Menkeano adservantur; cum synonymia critica et novarum specierum diagnosibus. Pyrmonti, p. 91.

Metcalfe, I., 1995. Gondwana dispersión and Asian accretion. J. Geol. B 5-6, 223-226.

Metcalfe, I., 1996. Gondwanaland dispersion, Asian accretion and evolution of Eastern Tethys. Aust. J. Earth Sci. 43, 605-623.

Metcalfe, I., 1999. Gondwana dispersion and Asian accretion: An overview. In: Metcalfe, I. (Ed.), Gondwana Dispersion and Asian AccretionFinal Results Volume for IGCP Project 321. Balkema, Rotterdam, pp. 9-28.

Metcalfe, I., 2002. Permian tectonic framework and palaeogeography of SE Asia. J. Asian Earth Sci. 20, 551-566.

Metcalfe, I., 2009. Late Palaeozoic and Mesozoic tectonic and palaeogeographical evolution of SE Asia. In: Buffetaut, E., Cuny, G., Le Loeuff, J., Suteethorn, V. (Eds.), Late Palaeozoic and Mesozoic Ecosystems in SE Asia. The Geological Society, London, Special Publications 315, pp. 7-23.

Mezzalira, S., 1989. Os fósseis do Estado de São Paulo. rev. atual. São Paulo, Secretaria do Meio Ambiente/Instituto Geológico (Pesquisa), second ed., p. 142.

Milani, E.J., Melo, J.H.G., Souza, P.A., Fernandes, L.A., França, A.B., 2007. Bacia do Paraná. In: Milani, E.J., Rangel, H.D., Bueno, G.V., Stica, J.M., Winter, W.R., Caixeta, J.M., Pessoa Neto, O.C. (Eds.), Bacias Sedimentares Brasileiras e Cartas Estratigráficas. Boletim de Geociências da Petrobrás, Rio de Janeiro vol. 15, pp. 265-287.

Mineropar, 2007. Mapeamento geológico da folha de Ponta Grossa (1:100.000). Governo do Estado do Paraná, Relatório Final, 169 pp.

Mori, A.L.O., Souza, P.A., Marques, J.C., Lopes, R.C., 2012. A new U-Pb zircon age dating and palynological data from a Lower Permian section of the southernmost Paraná Basin Brazil: Biochronostratigraphical and geochronological implications for Gondwanan correlations. Gondwana Res. 21, 654-669.

Mory, A.J., Backhouse, J., 1997. Permian stratigraphy and palynology of the Carnarvon Basin, Western Australia. Western Australia Geological Survey, Report 51 (46 pp.).

Mory, A.J., Haig, D.W., 2011. Permian-Carboniferous geology of the northern Perth and Southern Carnarvon Basins. Western Australia-a field guide: Geological Survey of Western Australia, Record 2011/14 (65 pp.).

Mory, A.J., Redfern, J., Martin, J.R., 2008. A review of Permian-Carboniferous glacial deposits in Western Australia. In: Fielding, C.R., Frank, T.D., Isbell, J.L. (Eds.), Resolving the Late Paleozoic Ice Age in Time and Space. The Geological Society of America, Special Paper 441, pp. 29-39.

Mouro, L.D., Fernandes, A.C.S., Rogerio, D.W., Fonseca, V.M., 2014. First articulated ponge from the Paleozoico of Brazil, and a new organization of the Order Hemidiscosa. J. Paleontol. 88, 171-178.

Muir-Wood, H.M., 1955. A history of the classification of the Phylum Brachiopoda. British Museum (Natural History), London (v + 124 pp.). 
Muir-Wood, H.M., 1962. On the morphology and classification of the Brachiopod Suborder Chonetoidea. British Museum (Natural History), London, Monograph (viii + 132 pp.).

Muir-Wood, H.M., Cooper, G.A., 1960. Morphology, classification and life habits of the Productoidea (Brachiopoda). Mem. Geol. Soc. Am. 81 (447 pp.)

Nalivkin, 1979. Brakhiopody turneiskogo Iarusa Urala (Brachiopods of the Tournaisian of the Urals). Nauka, Leningrad (248 pp.).

Neves, J.P., Anelli, L.E., Pagani, M.A., Simões, M.G., 2014a. Late Palaeozoic South American pectinids revised: biostratigraphical and palaeogeographical implications. Alcheringa 38, 281-295.

Neves, J.P., Anelli, L.E., Simões, M.G., 2014b. Early Permian post-glacial bivalve faunas of the Itararé Group, Paraná Basin, Brazil: paleoecology and biocorrelations with South American intraplate basins. J. S. Am. Earth Sci. 52, 203-233.

Nicoll, R.S., Metcalfe, I., 1998. Early and Middle Permian conodonts from the Canning and Southern Carnarvon Basin, Western Australia: Their implications for regional biogeography and palaeoclimatology. Proc. Roy. Soc. Victoria 110, 419-461.

Oliveira, E.P., 1930. Fósseis marinhos na Série Itararé no Estado de Santa Catarina. An. Acad. Bras. Cienc. 2, 17-21.

Oliveira, E.P., 1936. Um novo braquiopod da Serie Itararé. Notas Preliminares e Estudos, Divisão de Geologia e Mineralogia 5, pp. 8-10.

Pagani, M.A., 1998. Braquiópodos y gastrópodos Pérmicos de las Formaciones Piedra Azul y Bonete (Provincia de Buenos Aires). Ameghiniana 35, 265-270.

Pagani, M.A., 2000. Bivalvos del Pérmico inferior de la Formación Bonete, Sierras Australes (provincia de Buenos Aires, Argentina). Ameghiniana 37, 301-320.

Pagani, M.A., Taboada, A.C., 2011. The Cisuralian faunal succession in Patagonia (TepuelGenoa Basin, Argentina): an updated brachiopod biostratigraphic scheme. Assoc. Australas. Paleontol. Mem. 41, 339-350.

Pángaro, F., Ramos, V.A., 2015. The Hesperides basin: a continental-scale upper Palaeozoic to Triassic basin in Southern Gondwana. Basin Res. 1-27.

Pinto, I.D., 1949. Contribuição ao reconhecimento de novos fósseis na Formação Maricá (afloramento Budó). Faculdade de Filosofia, Universidade do Rio Grande do Sul 2 (6 pp.).

Prendergast, KL, 1943. Permian productinae and Strophalosiinae of Western Australia J. R. Soc. West. Aust. 28, 1-73.

Racheboeuf, P.R., 2000. Chonetidina. In: Kaesler, R.L. (Ed.), Treatise on Invertebrate Paleontology, Part HBrachiopoda (revised) vol. 2. The Geological Society of America and Paleontological Institute, Boulder, Colorado and Lawrence, Kansas, pp. 362-423.

Ramos, V.A., Naipauer, M., 2014. Patagonia: where does it come from? J. Iber. Geol. 40 367-379.

Reed, F.R.C., 1928. A Permo-Carboniferous marine fauna from the Umaria Coal Field. Records of the Geological Survey of India 60, pp. 367-398.

Reed, F.R.C., 1932. New Fossils from Agglomeratic Slate of Kashmir. Geol. Surv. India Mem. Palaeontologia Ind. 20 (79 pp.)

Reed, F.R.C., 1936. Some fossils from the Eurydesma and Conularia Beds (Punjabian) of the Salt Range. Mem. Palaeontologia Ind. 23, 1-36.

Roberts, J., Hunt, J.W., Thompson, D.M., 1976. Late Carboniferous marine invertebrate zones of eastern Australia. Alcheringa 1, 197-225.

Rocha Campos, A.C., 1966. Novas ocorrências de fósseis marinhos no Grupo Tubarão em São Paulo e Santa Catarina. Bol. Soc. Brasil. Geol. 15, 5-13.

Rocha Campos, A.C., 1967. The Tubarão Group in the Brazilian portion of Paraná Basin. In: Bigarella, J.J., Becker, R.D., Pinto, I.D. (Eds.), Problems in Brazilian Gondwana Geology, I International Symposium on the Gondwana stratigraphy and paleontology. Curitiba, pp. 27-102.

Rocha Campos, A.C., 1969. Moluscos e braquiópodes Eogondvânicos do Brasil e Argentina Full professor thesis. Universidade de São Paulo.

Rocha Campos, A.C., 1970. Upper Paleozoic bivalves and gastropods of Brazil and Argentina: a review. Proceedings Papers, Second Gondwana Symposium (Pretoria), pp. 605-612.

Rocha Campos, A.C., de Carvalho, R.G., 1975. Two new bivalves from the Permian Eurydesma fauna of eastern Argentina. Boletim Instituto de Geociencias 6. Universidade de Sao Paulo, pp. 185-191.

Rocha Campos, A.C., Rösler, O., 1978. Late Paleozoic faunal and floral successions in the Paraná Basin, southern Brazil. Boletim IG-USP, Série Científica 9, pp. 1-16.

Rocha Campos, A.C., Basei, M.A.S., Nutman, A.P., Santos, P.D., 2006. SHRIMP U-Pb zircon geochronological calibration of the Late Paleozoic supersequence, Paraná Basin Brazil. South American Symposium on Isotope Geology 5 pp. 298-301.

Rocha Campos, A.C., Basei, M.A.S., Nutman, A., dos Santos, P.R., 2007. SHRIMP UePb ages of the late Paleozoic sedimentary sequence, Paraná Basin, Brazil. 40th Simpósio sobre cronoestratigrafia da Bacia do Paraná, XX Congresso Brasileiro de Paleontologia. Sociedade Brasileira de Paleontologia, Búzios. Boletim de Resumos 33.

Rocha Campos, A.C., Basei, M.A.S., Nutman, A.P., Kleiman, L.E., Varela, R., Llambías, E., Canile, F.M., da Rosa, O. de C.R., 2011. 30 million years of Permian volcanism recorded in the Choiyoi igneous province (W Argentina) and their source for younger ash fall deposits in the Paraná Basin: SHRIMP UePb zircon geochronology evidence. Gondwana Res. 19, 509-523.

Runnegar, B., 1979. Ecology of Eurydesma and the Eurydesma fauna, Permian of eastern Australia. Alcheringa 3, 261-285.

Rygel, M.C., Fielding, C.R., Frank, T.D., Birgenheier, L.P., 2008. The magnitude of late Paleozoic glacioeustatic fluctuations: A synthesis. J. Sediment. Res. 78, 500-511.

SACS (South African Committee for Stratigraphy), 1980. Stratigraphy of South Africa. Part I: Lithostratigraphy of the Republic of South Africa, southwest Africa/Namibia and the Republic of Bophuthatswana, Transkei and Venda (L.E. Kent, compiler). Geological Survey of South Africa Handbook 8, pp. 1-690

Sahni, M.R., Srivastava, J.P., 1956. Discovery of Eurydesma and Conularia in the easter Himalaya and description of associated faunas. J. Palaeontol. Soc. India 1, 202-214.
Santos, P.R., Rocha-Campos, A.C., Canuto, J.R., 1996. Patterns of Late Palaeozoic deglaciation in the Paraná Basin, Brazil. Palaeogeogr. Palaeoclimatol. Palaeoecol. 125, $165-184$

Sarytcheva, T.G., Sokolskaja, A.N., 1959. O klassifikatsin lozhnoporistykh brakhiopod. (On the Classification of Pseudopunctate Brachiopods.). Dokl. Akad. Nauk SSSR 125 , 181-184 (in Russian).

Schlotheim, E.F. von, 1816. Beitrage zur Naturgeschichte der Versteinerungen in geognostischer Hinsicht. Akademi Wissenschaften Munchen Mathematischephysike Klasse Denkschriften 6, pp. 13-36.

Schneider, R.L., Mühlman, H., Tommasi, E., Medeiros, R.A.A., Daemon, R.F., Nogueira, A.A., 1974. Revisão estratigráfica da Bacia do Paraná. XXVIII Congresso Brasileiro de Geologia. Sociedade Brasileira de Geologia, Porto Alegre, pp. 41-65.

Sengör, A.M.C., 1979. Mid-Mesozoic closure of Permo-Triassic Tethys and its implications. Nature 279, 590-593

Sengör, A.M.C., 1984. The Cimmeride orogenic system and the tectonics of Eurasia. Geol. Soc. Am. Spec. Pap. 195, 1-74.

Shen, S.Z., Archbold, N.W., Shi, G.R., 2001. A Lopingian (Late Permian) brachiopod fauna from the Qubuerga Formation at Shengmi in the Mount Qomolangma Region of southern Xizang (Tibet), China. J. Paleontol. 75, 274-283.

Shen, S.Z., Zhang, H., Shi, G.R., Li, W.Z., Xie, J.F., Mu, L., Fan, J.X., 2013. Early Permian (Cisuralian) global brachiopod palaeobiogeography. Gondwana Res. 24, 104-124.

Shi, G.R., Archbold, N.W., 1993. Distribution of Asselian to Tastubian (Early Permian) Circum-Pacific brachiopod faunas. Assoc. Australas. Paleontol. Mem. 15 (343-251).

Shi, G.R., Archbold, N.W., 1996. A Quantitative Palaeobiogeographical analysis on the distribution of Sterlitamakian-Aktastinian (Early Permian) Western Pacific Brachiopod faunas. Hist. Biol. 11, 101-123.

Shi, G.R., Waterhouse, J.B., 1996. Lower Permian Brachiopods and Molluscs from the Upper Jungle Creek Formation, Northern Yukon Territory, Canada. Bull. Geol. Surv, Can. 42, 1-241.

Shi, G.R., Waterhouse, J.B., 2010. Late Palaeozoic global changes affecting high-latitude environments and biotas: An introduction. Palaeogeogr. Palaeoclimatol. Palaeoecol. 298, $1-16$.

Shi, G.R., Archbold, N.W., Zongje, Fang, 1995. The Biostratigraphical and Palaeogeographical significance of an Early Permian Brachiopod fauna from the Dingjiazhai Formation, Baoshan Block, Western Yunnan, China. J. Geol. B 5-6, $63-74$

Shi, G.R., Zongjie, Fang, Archbold, N.W., 1996. An Early Permian brachiopod fauna of Gondwanan affinity from Baoshan block, western Yunnan, China. Alcheringa 20, 81-101.

Shi, G.R., Leeman, M.S., Tan, B.K., 1997. Early Permian brachiopods from the Singa Formation of Langkawi Island, northwestern Peninsular Malaysia: bioestratigraphical and biogeographical implications. The International Conference on Stratigraphy and Tectonic Evolution of Southeast Asia and the South Pacific. Bangkok, Thailand, pp. 62-72.

Shi, G.R., Shen, S.Z., Zhan, L.P., 2003. A Guadalupian-Lopingian (Middle to Late Permian) brachiopod fauna from the Juripu Formation in the Yarlung-Zangbo Suture Zone, southern Tibet, China. J. Paleontol. 77, 1053-1068.

Simanauskas, T., 1991. Lissochonetes jachalensis Amos, 1961. (Brachiopoda, Chonetacea). Redescripcion Morfologica y Ontogenia. Ameghiniana 28, 135-143.

Simas, M.W., Guerra-Sommer, M., Cazzulo-Klepzig, M., Menegat, R., Santos, J.O.S., Ferreira, J.A.F., Degani-Schmidt, I., 2012. Geochronological correlation of the main coal interval in Brazilian Lower Permian: Radiometric dating of tonstein and calibration of biostratigraphic framework. J. S. Am. Earth Sci. 39, 1-15.

Simas, M.W., Guerra-Sommer, M., Mendoça Filho, J.G., Cazzulo-Klepzig, M., Formoso, M.L.L., Degani-Schmidt, I., 2013. An accurate record of volcanic ash fall deposition as characterized by dispersed organic matter in a Lower Permian tonstein layer (Faxinal Coalfield, Paraná Basin, Brazil). Geol. Acta 11 (1), 45-57. http://dx.doi.org/ 10.1344/105.000001835.

Simões, M.G., Rocha-Campos, A.C., Anelli, L.E., 1998. Paleoecology and evolution of Permian bivalve faunas (Paraná Basin) In Brazil. In: Johnston, P.A., Haggart, J.W. (Eds.), Bivalves - An Eon of evolution - paleobiological studies honoring Norman D. Newell. Calgary University Press, Canada, pp. 443-452.

Simões, M.G., Neves, J.P., Anelli, L.E., Weinschütz, L.C., 2012. Permian bivalves of the Taciba Formation, Itararé Group, Paraná Basin, and their biostratigraphic significance. Boletim IG-USP, Série Científica 12, pp. 71-82.

Simões, M.G., Neves, J.P., Taboada, A.C., 2015. Permian bivalves of the Capivari Formation, Itararé Group (State of São Paulo): stratigraphic and biostratigraphic implications. XXIV Congresso Brasileiro de Paleontologia (Crato, Agosto, 2-6), Abstract, p. 169.

Singh, T., Archbold, N.W., 1993. Brachiopoda from the Early Permian of the Eastern Himalaya. Alcheringa 17, 55-75.

Skwarko, S.K., 1993. Palaeontology of the Permian of Western Australia. Bull. Geol. Surv. W. Aust. 136 (417 pp.)

Sprechmann, P., Da Silva, J., Gautcher, C., Montaña, J., Herrera, Z., 2001. Las concreciones fosilíferas de la Formación San Gregorio del Uruguay (Carbonífero Superior?-Pérmico Inferior?): sus implicancias paleoecológicas y paleoclimáticas. $11^{\circ}$ Congreso Latinoamericano de Geología (Montevideo), Actas 207, pp. 10-16.

Stehli, F.G., 1954. Lower Leonardian Brachiopoda of the Sierra Diablo. Bull. Am. Mus. Nat. Hist. 105, 257-358.

Stephenson, M.H., 2009. The age of the Carboniferous-Permian Converrucosisporites confluens Oppel Biozone: New data from the Ganigobis shale Member (Dwyka Group) of Namibia. Palynology 33, 167-177.

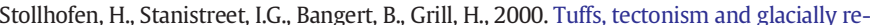
lated sea-level changes, Carboniferous-Permian, southern Namibia. Palaeogeogr. Palaeoclimatol. Palaeoecol. 161, 127-150.

Stollhofen, H., Werner, M., Stanistreet, I.G., Armstrong, R.A., 2008. Single-zircon U-Pb dating of Carboniferous-Permian tuffs, Namibia, and the intercontinental deglaciation 
cycle framework. In: Fielding, C.R., Frank, T.D., Isbell, J.L. (Eds.), Resolving the Late Paleozoic Ice Age in Time and Space. Geological Society of America Special Paper 441, pp. 83-96.

Sun, Y., Baliński, A., 2008. Silicified Mississippian brachiopods from Muhua, southern China: Lingulids, craniids, strophomenids, productids, orthotetids, and orthids. Acta Palaeontol. Pol. 53, 485-524.

Taboada, A.C., 2010. Mississippian-Cisuralian brachiopods from western Argentina: a tool for median to high-latitude correlation, palaeobiogeographic and palaeoclimatic reconstruction. Palaeogeogr. Palaeoclimatol. Palaeoecol. 298, 152-173.

Taboada, A.C., Pagani, M.A., 2010. The coupled occurrence of Cimmeriella-Jakutoproductus (Brachiopoda: Productidina) in Patagonia: implications for Early Permian high to middle paleolatitudinal correlations and paleoclimatic reconstruction. Geol. Acta 8, 513-534.

Taboada, A.C., Shi, G.R., 2009. Yagonia Roberts (Brachiopoda: Chonetidina) from the Malimán Formation, Lower Carboniferous of western Argentina: palaeobiogeographical implications. Alcheringa 33, 223-235.

Taboada, A.C., Shi, G.R., 2011. Taxonomic review and evolutionary trends of Levipustulini and Absenticostini (Brachiopoda) from Argentina: palaeobiogeographic and palaeoclimatic implications. Assoc. Australas. Paleontol. Mem. 41, 87-114.

Taboada, A.C., Pagani, M.A., Isbell, J.L., 2013. Las faunas neopaleozoicas subpolares de Patagonia (Cuenca Tepuel-Genoa): biocorrelación, vinculación/aislamiento paleobiogeográfico e implicancias paleogeográficas. VI Simposio Argentino del Palezoico Superior (Buenos Aires, 16-17 de Diciembre de 2013), p. 3.

Taboada, A.C., Mory, A., Shi, G.R., Pinilla, K., 2015. The Early Permian brachiopod fauna from Pasminco BW 9 borehole (Calytrix Formation) on the Barbwire Terrace, Canning Basin, Western Australia. Alcheringa 39, 207-223.

Teichert, C., Glenister, B.F., 1952. Lower Permian ammonoids fromthe Irwin Basin, Western Australia. J. Paleontol. 26, 12-23.

Thomas, G.A., 1958. The Permian Orthotetacea of Western Australia. Bull. Bur. Mineral Resour. Geol. Geophys. 39 (159 pp.).

Thomas, G.A., 1971. Carboniferous and Early Permian Brachiopods from Western and Northern Australia. Bull. Bur. Mineral Resour. Geol. Geophys. 56 (276 pp.).

Tohver, E., Cawood, P.A., Rossello, E.A., Riccomini, C., 2007. Demise of the Gondwana Ice Sheet in SW Gondwana: Time Constraints from U-Pb Zircon Ages. Memorias CDRom. GEOSUR 2007 International Geological Congress on the Southern Hemisphere (Santiago de Chile, 19/20 November 2007).

Tohver, E., Cawood, P.A., Rossello, E., López de Luchi, M.G., Rapalini, A., Jourdan, F., 2008. New SHRIMP U-Pb and 40Ar/39Ar constraints on the crustal stabilization of southern South America, from the margin of the Rio de Plata (Sierra de Ventana) craton to northern Patagonia. American Geophysical Union. Fall Meeting, EOS (Abstract), pp. T23C-2052.

Ueno, K., 2003. The Permian fusulinoidean faunas of the Sibumasu and Baoshan blocks: their implications for the paleogeographic and paleoclimatologic reconstruction of the Cimmerian Continent. Palaeogeogr. Palaeoclimatol. Palaeoecol. 193, 1-24.

Veevers, J.J., Powell, C., 1987. Late Paleozoic glacial episodes in Gondwanaland reflected in transgressive-regressive depositional sequences in Euramerica. Geol. Soc. Am. Bull. 98, 475-487.

Waagen, W., 1881. Salt Range Fossils: Productus Limestone Fossils: Pelecypoda. Geol. Surv. India Mem. Palaeontologia Ind. 1, 185-328.

Waagen, W., 1883. Salt Range Fossils. Productus-Limestone Fossils. Geol. Surv. India Mem. Palaeontologia Ind. 2, 39-546.

Waagen, W., 1884. Salt Range Fossils. I. Productus-Limestone Fossils. Geol. Surv. India Mem. Palaeontologia Ind. 3, 547-728.

Waagen, W., 1885. Salt Range fossils.Productus-limestone fossils. Geol. Surv. India Mem. Palaeontologia Ind. 5, 771-834.

Waterhouse, J.B., 1964. Permian Brachiopods of New Zealand. Geol. Surv. NZ Palaeontological Bull. 35, 1-287.

Waterhouse, J.B., 1970. Gondwanan occurrences of the Upper Paleozoic brachiopod Stepanoviella. J. Paleontol. 44, 37-50.

Waterhouse, J.B., 1975. New Permian and Triassic brachiopod taxa. Department of Geology of the University of Queensland papers (new series) 7, pp. 1-23.

Waterhouse, J.B., 1978. Permian Brachiopoda and Mollusca from North-west Nepal. Palaeontogr. Abt. A 160, 1-175.

Waterhouse, J.B., 1983. New Permian invertebrate genera from East Australian segment of Gondwana. Bull. Indian Geol. Assoc. 16, 153-158.
Waterhouse, J.B., 1986. A new Permian brachiopod genus related to Ambikella Sahni and Srivastava. Bull. Indian Geol. Assoc. 19, 109-112.

Waterhouse, J.B., 2001. Late Paleozoic Brachiopoda and Mollusca from Wairaki Downs, New Zealand.With notes on Scyphozoa and Triassic ammonoids and new classifications of Linoproductoidea (Brachiopoda) and Pectinida (Bivalvia). Earthwise 3 (195 pp.).

Waterhouse, J.B., 2008. Golden Spikes and Black Flags -macro-invertebrate faunal Zones for the Permian of East Australia. Proc. Roy. Soc. Victoria 120, 345-372.

Waterhouse, J.B., 2011. Origin and evolution of Permian brachiopods of Australia. Assoc. Australas. Paleontol. Mem. 41, 205-228.

Waterhouse, J.B., 2013. The Evolution and Classification of Productida (Brachiopoda). Earthwise 10 (535 pp.).

Weinschutz, L.C., Castro, J.C., 2004. Arcabouço cronoestratigráfico da Formação Mafra (intervalo médio) na região de Rio Negro/PR-Mafra/SC, borda leste da Bacia do Paraná 57. Revista da Escola de Minas de Ouro Preto, pp. 151-156.

Weinschutz, L.C., Castro, J.C., 2005. A sequência Mafra Superior/Rio do Sul Inferior (Grupo Itararé, Permocarbonífero), em sondagens testemunhadas da região de Mafra (SC) margem leste da Bacia do Paraná. Geociências UNESP 24, 131-141.

Weinschutz, L.C., Castro, J.C., 2006. Seqüências deposicionais da Formação Taciba (Grupo Itararé, Neocarbonífero a Eopermiano) na região de Mafra (SC), Bacia do Paraná. Rev. Bras. Geosci. 36, 243-252.

Werner, M., 2006. The stratigraphy, sedimentology and age of the Late Palaeozoic Mesosaurus in land sea. SW Gondwana-New implications from studies on sediments and altered Pyroclastic layers of the Dwyka and Ecca Group (Lower Karroo Supergroup) in southern Namibia. University of Wurzburg, Wurzburg (425 p., http// www.opus-bayern.de/uni-wuerzburg/volltexte/2007/2175/).

Williams, A., 1953. The classification of the strophomenoid brachiopods. Washington Academy of Sciences Journal 43. Instituto de Geociências, Universidade Federal do Rio Grande do Sul, Porto Alegre, pp. 1-13 84 p. (Magister thesis).

Williams, A., Brunton, C.H.C., 2000. Suborder Orthotetidina. In: Kaesler, R.L. (Ed.), Treatise on Invertebrate PaleontologyPt. H. Brachiopoda (revised) 3. Geological Society of America and University of Kansas Press, pp. 644-689.

Williams, A., Carlson, S.J., Brunton, C.H.C., Holmer, L.E., Popov, L.E., 1996. A supra-ordinal classification of the Brachiopoda. Philos. Trans. R. Soc. Lond. B 351, 1171-1193.

Williams, A., Carlson, S.J., Brunton, C.H.C., 2000. Linguliformea. In: Kaesler, R.L. (Ed.), Treatise on Invertebrate PaleontologyPt. H. Brachiopoda (revised) 2. Geological Society of America and University of Kansas Press, pp. 30-156.

Wilner, E., 2014. Análise preliminar das associações naturais de conodontes do Folhelho Lontras, Grupo Itararé, Cisuraliano da Bacia do Paraná na região de Mafra, SC. Master Dissertation. Universidade Federal do Rio Grande do Sul, Porto Alegre, RS (83 pp.).

Woodworth, B., 1912. Geological expedition to Brazil and Chile 1908-1909. Bull. Mus Comp. Zool. Harv. Univ. 46, 11-37.

Wopfner, H., Casshyap, S.M., 1997. Transition from Freezing to Subtropical Climates in the Permo-Carboniferous of Afro-Arabia and India. In: Martini, I.P. (Ed.), Late glacial and postglacial environmental changes; Quaternary, Carboniferous-Permian, and Proterozoic. Oxford University Press, New York, NY, United States (USA), pp. 192-212.

Xinsheng, L.B.C., 1983. Discovery of Eurydesma fauna from Rutog, northwest Xizang (Tibet) and its biogeographic significance. Earth Sci. J. China Univ. Geosci. 1, 008.

Yanishevskiy, M.E., 1935. Opisanie fauny iz osnovaniya uglenosnoi tolshi Kuznetskogo Baseina (Description of the fauna from the base of the coal-bearing series of the Kuznets Basin). Uchenye Zapiski Leningradskogo Gosudarstvennogo Universiteta Seriya Geologo-Pochvennykh Geograficheskaya 1, pp. 53-76 (in Russian).

Zambito, J.J., Schemm-Gregory, M., 2013. Revised taxonomy and autecology for the brachiopod genus Ambocoelia in the Middle and Late Devonian Northern Appalachian Basin (USA). J. Paleontol. 87, 277-288.

Zavodowsky, V.M., 1960. Novyy Permskiy Predstavitel' Konokardiid Severo-Vostoka SSSR [New Permian representives of the Conocardiidae from northeastern SSSR]. Novye Vidy Drevnikh Rasteniy i Bespozvonochnykh SSSR [New Species of Fossil Plants and Invertebrates of the USSR] 1, pp. 31-33.

Zhang, Y.C., Shi, G.R., Shen, S.Z., 2013. A review of Permian stratigraphy, palaeobiogeography and palaeogeography of the Qinghai-Tibet Plateau. Gondwana Res. 24, 55-76. 